\title{
SHORT PAPERS ON WATER SUPPLIES AND ENGINEERING GEOLOGY, ALASKA HIGHWAY, 1943-1944
}

By C.V. Theis

U.S. Geological Survey

Open-File Report 91-80

Prepared in cooperation with the U.S. Corps of Engineers

Reston, Virginia 


\title{
U.S. DEPARTMENT OF THE INTERIOR
}

\author{
MANUEL LUJAN JR., Secretary \\ U.S. GEOLOGICAL SURVEY
}

Dallas L. Peck, Director

Copies of the report can be purchased from:

U.S. Geological Survey

Books and Open-File Reports

Box 25425, Federal Center, Bldg. 41

Denver, Colorado 80225 


\section{FOREWORD}

During his long and productive life, C.V. Theis, regarded by his scientific peers as the father of quantitative ground-water hydrology, authored about 150 reports. About one-third of these reports were prepared for various U.S. Federal and military agencies during and following World War II and never released to the public. These agencies (or their present day equivalents) have agreed that it is desirable to make these reports available for study by historians, scholars, and others interested in the development of the science of ground-water hydrology. 


\section{CONTENTS}

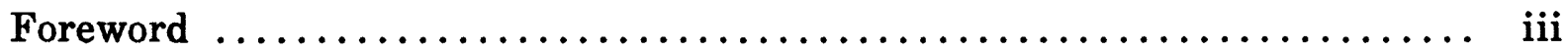

Well water supply at Namao $(21$ October, 1943) $\ldots \ldots \ldots \ldots \ldots \ldots \ldots \ldots$.

Possible sources of water supply at Namao $(25$ November, 1943) $\ldots \ldots \ldots \ldots \ldots \quad 4$

Further drilling at Namao $(14$ January, 1944) $\ldots \ldots \ldots \ldots \ldots \ldots \ldots \ldots$

Water supply at Namao $(24$ February, 1944$) \quad \ldots \ldots \ldots \ldots \ldots \ldots \ldots \ldots . \ldots$

Use of wells to dispose of effluent from the sewage treatment plant at Namao (9 December, 1943) $\ldots \ldots \ldots \ldots \ldots \ldots \ldots \ldots \ldots \ldots \ldots \ldots . \ldots \ldots$

Sites to be drilled for water in the Fairbanks District (11 November, 1943) $\ldots . .13$

Ground water conditions at Fort Nelson Airport ( 7 December, 1943) ....... 16

Water supplies for relay and repeater stations on the Alaska

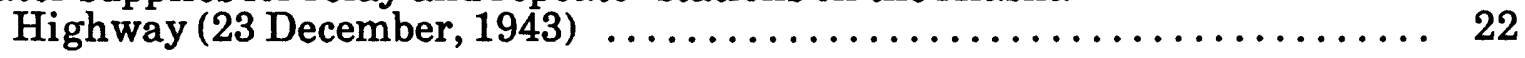

Water supplies for maintenance stations in the Dawson Creek district (30 December, 1943) $\ldots \ldots \ldots \ldots \ldots \ldots \ldots \ldots \ldots \ldots \ldots . \ldots \ldots$

Water well for fire protection on the Canadian side of Watson Lake Airfield (24 January, 1944) ........................ 36

Survey of permafrost conditions at Koidern Repeater

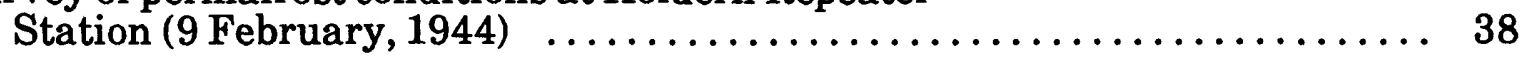

Pumping test on well at N-0 $(10$ February, 1944) $\ldots \ldots \ldots \ldots \ldots \ldots \ldots \ldots .42$

Grande Prairie Air Base water supply (16 February, 1944) $\ldots \ldots \ldots \ldots \ldots \ldots 43$

Study of water supply for the Alaska Wing Stations (29 February, 1944） $\ldots .444$

Foundation movement at Northway Repeater Station (9 March, 1944) . .... 51

Installation of underground gasoline storage tanks (15 March, 1944) $\ldots \ldots \ldots \quad 54$

Foundation conditions at Northway Hanger (17 March, 1944) .......... 55

Foundation conditions at the power house (Building No. 116) at Northway Airport (18 March, 1944) 


\section{Well Water Supply at Namao \\ By Charles V. Theis}

21 October 1943

1. Water requirements at the Satellite Field at Namao are understood to be about 25,000 gallons per day, or 15 to 20 gallons per minute.

2. The present well starts about 500 feet above the base of the Edmonton formation of Upper Cretaceous Age. The Edmonton formation consists of dark, very poorly consolidated shales containing bentonite, with subordinate silty fine sandstones and coals. According to Dr. R.L. Rutherford, of the University of Alberta, the coals are the best aquifers of the formation. The water in the formation generally contains sodium bicarbonate and is very soft, as a result of base exchange with the bentonite. At a depth of about 500 feet at this locality, Bearpaw shales containing highly mineralized water would probably be struck.

3. When visited on 18 October, the well at Namao was drilling at a depth of 450 feet. A log down to 300 feet was furnished by Mr. Broom (p. 2). The "limestone" noted in the log is probably ironstone in beds a few inches thick. The bailing test at 115 feet is doubtless over-optimistic.

4. Many wells in the vicinity of Namao Field provide domestic and stock water to the residents. The records of a great number of these wells have been collected by Dr. Rutherford. A good part of the wells are shallow and obtain water from the glacial materials. Others, somewhat deeper, obtain adequate supplies for farm use at depths from 200 to 300 feet from the Edmonton formation. The best well in the vicinity is that at the Horrick Brothers Dairy in the Northeast Quarter of Section 5, Township 54 North, Range 24 West. This well is 3 inches in diameter and was drilled to a depth of 197 feet. It supplies five houses and a dairy using 200 head of cattle. The quantity of water needed for the dairy is probably smaller but of the same order of magnitude as that needed at the airfield.

5. The following recommendations are made:

a. The attempt to provide the water supply of the airfield by means of wells will probably be successful and should be continued. 
Glacial Beds

Blue clay

33

33

Clay and gravel

Sand with water

Edmonton formation

White chalk (probably bentonitic bed) 58

Clay with some rock; shale

Clay, limestone, and shale

Limestone and shale

Coal; some water

Sand and clay

Clay (probably with some sand)

(Water bailed at 25 g.p.m. at 115 feet)

Cave; probably water sand

Clay

Black clay

Clay and old vegetation

Hard clay

32

190

Trace of coal

Coal

Coal and clay

10

210

(Missing)

28

238

Hard slate

Clay and slate

20

265

(Missing)

5

270

Quick sand and slate

Blue clay and shale

25

Water at 373 feet in beds reported to be also "clay and shale." 
b. The present well should be tested by pumps as soon as a suitable pump can be procured.

(1) The well should be developed by surging and pumping for short periods at as high a pumping rate as possible.

(2) When the water has cleared the well, it should be pumped at a constant rate for about 10 hours and the water level noted at intervals while the well is being pumped. The pump should then be stopped, and water level measurements should be made at 15-minute intervals for an hour and halfhourly intervals for another 9 hours. (The rate of recovery gives a clearer indication of the character of the aquifer than does the drawdown during pumping, for it is influenced only to a small extent by the type of perforation or other characteristics of the well installation).

c. If the pumping test indicates that the well will produce not quite enough water to meet the requirements, it may be deepened to between 500 and 550 feet, in the hope of picking up an additional quantity of water.

d. During any further drilling, samples of the material penetrated by the drill should be taken and preserved every 10 feet and at every change in strata. These samples should be washed, plainly labeled as to depth, and preserved for the inspection of a geologist. A sample taken from the material clinging to the bit should be included with the washed sample where possible. No good logs of wells in the vicinity of the airfield are available. The sandstones and, to a lesser extent, the coals are erratic in occurrence, and no predictions can be made regarding future wells without such base data.

c. If only part of the required water supply can be obtained from the present well, other wells should be drilled at about 500 -foot centers until the requisite supply is obtained. Drilling samples of materials penetrated should be carefully taken and preserved as indicated in d. above. 


\section{Possible Sources of Water Supply at Namao}

By Charles V. Theis

25 November 1943

\section{SECTION I--STATEMENT OF PROBLEM}

1. It is understood that the amount of water required at the Edmonton Satellite Field will be that required for a force of 356 men, or about 25,000 gallons a day, which, if provided within 16 hours, is equivalent to an average flow of about 25 gallons a minute. Storage for 90,000 gallons of water for fire protection will be provided; although apparently no directive requires that this be replenished in any specified time, the desirability of prompt replenishment should be kept in mind.

2. The possible sources of water supply are (a) comparatively shallow wells about 200 feet in depth or less, (b) deeper wells about 750 feet in depth, (c) the Sturgeon River, and (d) the Edmonton city supply.

3. The characteristics of these various supplies are discussed generally in ensuring sections of this report, followed by a general summary and recommendations.

\section{SECTION II--COMPARATIVELY SHALLOW WELLS}

1. Three wells have been drilled at the site. Of these, No. 1, located 203.8 feet north of North Ave. and 60.2 feet east of C Street produced little pertinent information and can be disregarded.

2. Well No. 2, 170 feet south of Central Avenue and 80 feet east of C Street, attained a depth of 507 feet and produced small amounts of water at 46,78, 125 (probably), 273, 373, and 424 feet according to the log. The rocks passed through were largely shale with a few coal seams and some sandstone and sandy shale beds. The water was largely derived from coal seams and sandy beds. The well was bailed dry at 130 feet, but the rate of bailing was not determined and no pumping tests were made at any time. A water sample taken November 1 when the hole was 500 feet deep and uncased, contained 4930 parts per million of salt. Another sample, taken on November 3, after the hole had caved below a depth of 380 feet, contained 5580 parts of salt. A third sample taken November 4, after the hole had been closed with a clay plug below 380 feet, contained 5800 parts per million of salt. Inflammable gas, probably methane, was logged at 440 feet, and in sufficient quantity to burn at 445 feet. Oil and gas was logged at 460 feet.

3. Well No. 3, 190 feet south of South Avenue and 80 feet each of $\mathrm{C}$ street, encountered water at 55 feet and 75 feet. The static water level for these two horizons was 30 feet, and, when pumped for 12 hours at the rate of 2.2 gallons a minute, the water level drew down to the top of the strainer at 80 feet. A sample of water taken at this time contained 3006 parts per million total solids, of which 
2350 parts were sodium sulphate, 350 parts sodium carbonate, and 3 parts sodium chloride. Slightly more water was found at 110 feet and 132 feet, but a bailing test indicated that the total production of all aquifers encountered, including those previously tested, was only 2.5 gallons a minute. At 180 feet some water was struck but a sample taken at this depth contained 726 parts per million sodium chloride. At 273 feet more water was found, but a sample taken at this depth contained 2,343 parts of sodium chloride. As of 22 November the hole had been carried to a depth of 300 feet and welded casing had been seated at this depth shutting off all water.

4. Horrick Well. The best well known in the neighborhood of the Satellite Field is that of the Horrick Dairy, about two miles south of the present area offices. This well is 197 feet deep according to information given Dr. Rutherford of the University of Alberta. The static water level is reported to be 70 feet from the surface. When visited 22 November it was pumping 3 gallons a minute and was reported to continue at this rate about 12 hours a day; that is, to pump about 2,200 gallons a day. A sample of water taken on this date contained 2,062 part per million total solids, of which 1,045 were sodium sulphate and 922 sodium bicarbonate. It contained only 3 parts sodium chloride. The water has a "slick," alkali taste, but is considered one of the better waters of the neighborhood for domestic purposes.

5. Geologic and hydrologic interpretation of drilling. The wells start in glacial till which extends to a depth of about 30 or 40 feet. They then enter the Edmonton formation of Upper Cretaceous age, which consists of dark shale, with beds of coal and a few, comparatively thin, silty and fine-grained sandstones with low permeability. A significant proportion of bentonite is present in the various beds which causes natural zeolitic softening of the water with consequent increase in sodium content. The Bearpaw formation, occurring below the Edmonton, is also a shaley formation but contains much sodium chloride which the sluggish ground-water circulation has not yet flushed out. The Bearpaw is considered to pinch out north and east of Edmonton. It apparently occurs higher at the Satellite Field than had previously been suspected. It is probably between 200 and 300 feet thick at the field, according to Professor Allan of the University. Wells 2 and 3 apparently entered the salt bearing beds, and probably the Bearpaw, between 180 and 270 feet. It is possible that No. 2 well, 507 feet deep, passed entirely through these beds, inasmuch as the water when the hole was 500 feet deep was apparently somewhat less salty (4,900 parts per million) than when it had been plugged back to 380 feet ( 5,800 parts per million) although differences in the method of taking the sample may also be the cause of the differences in the samples.

6. Comparatively shallow wells as a source of water. Of the wells so far drilled, only No. 3 has been tested with any degree of adequacy for quality and quantity. These tests showed that the upper water is high in sodium sulphate, which would have a laxative effect, and that such wells will produce only 2 or 3 gallons a minute. However, no definite standards of human tolerance of alkali waters have been established and water of comparable quality is used for human consumption in the vicinity of the field. It is considered probable by the writer that by drilling perhaps 15 wells up to about 200 feet deep, water in the amount of 25 gallons a minute and of somewhat better quality than the sample from No. 3 well could be obtained. At a unit cost of $\$ 10.00$ per foot, reported to be the cost of these wells, the cost of the wells would be about $\$ 30,000$. To space the wells properly so that they would not unduly interfere with each other, probably a mile of connecting pipe would be necessary which would probably cost some $\$ 10,000$ 
additional. It is considered that the water could be drawn from about ten of these wells (the other five being relatively dry or containing water too highly mineralized) and that 10 small pumps perhaps aggregating $\$ 2500$ more would be required as well as a small power line to the individual pumps. The total cost to obtain the water would probably be about $\$ 50,000$. The disadvantages of attempting to supply water from such wells would be (1) the water would be of poor quality; (2) sufficient potable water might not be found; (3) some prospecting would be necessary and it would take considerable time to drill and finish such wells with the present equipment; and (4) the wells would not have sufficient capacity to replenish fire storage in less than several days even under careful rationing of water for domestic use.

7. Conclusion. Despite its relatively low expense, the disadvantages of the attempt to find water in shallow wells are too great, and it is recommended that the consideration of shallow wells as a source of water be abandoned.

\section{SECTION III--DEEPER WELLS}

1. Geology and hydrology. The Belly River formation underlies the Bearpaw at the Satellite Field. The Belly River consists of shales with some coarser and more permeable sandstones than those in the Edmonton. The quantity and chemical character of water in the Belly River in this vicinity are entirely unknown. Elsewhere, on the authority of Professor Allan, the Belly River has furnished some good wells. It seems possible, though improbable, that 2 or 3 wells to a depth of about 800 feet might produce the required water. If so the cost would be only some $\$ 35,000$ for the installation.

2. Conclusion. Wells to a depth of about 750 feet are a possible, but not probable, source of water that would be comparatively inexpensive. It is recommended (1) that the test be made, but (2) that immediate steps be taken to obtain another supply, and (3) in the event of successful drilling negotiations and plans for the other supply be abandoned in favor of deep wells.

\section{SECTION IV--THE STURGEON RIVER}

1. General Description. The Sturgeon River at St. Albert has a drainage area of 1,005 square miles, and at points near the Namao field of only a few square miles more. At its mouth near Ft. Saskatchewan some 40 miles distant the drainage area is only 1295 square miles. The River is typical of the small streams of glaciated regions. It meanders intricately through a silt-filled valley and passes through a number of broad shallow lakes. The nearest of these to the Satellite Field is Big Lake at St. Albert, which has an area of about 6 square miles, has a maximum depth at ordinary stage of about 4 feet and a depth at high water of about 8 feet.

2. Quality. A sample of water taken 22 November at the pumping plant furnishing water for construction purposes to the Satellite Field contained 520 parts per million total solids, including 210 parts sodium sulphate. The hardness was 313 parts per million. An earlier sample taken by area personnel, under conditions unknown at the present writing, contained 3,460 parts per million total solids including 3,067 parts sodium sulphate. A third sample taken 24 November under a 3-inch layer of ice contained 560 parts total solids and 195 parts sodium sulphate. The water from Sturgeon River at a point about $3 / 4$ mile below the intake for the line to the Satellite Field has been used for 15 years by the Northern Alberta Railway at all seasons of the year for boiler and other 
purposes. The water from Sturgeon River may therefore be assumed to be comparable to that of the Edmonton city supply and satisfactory from a chemical standpoint for domestic users at all seasons of the year.

3. Quantity Available. Records of the flow of the Sturgeon River at St. Albert from 1913 to 1927 have been published by the Canadian Water and Power Bureau. Records for winter months are generally missing. Nevertheless, the minimum discharge is recorded as "Nil" at various times, including March 1923 and August, September, and October 1921. At Fort Saskatachewan, the flow is given as "nil" for January and February 1923 and on various days in late spring, due to ice conditions, at other times according to incomplete records. The river is apparently frozen solid at St. Albert in most years according to Professor Allan. According to Mr. Tye, Chief Engineer, the Northern Alberta Railway obtains up to 15,000 gallons a day intermittently throughout the year at the pumping plant near the Namao field. The water accumulates in a large hole excavated by the river when the dam constructed by the railway was washed out about 1930. Mr. Tye is of the opinion that the amount of water needed for the Namao field could be obtained throughout the year by excavating a large and deep hole in the river bed. It should be pointed out, however, that the sump used by the railway may be filling slowly when the river itself is frozen by ground-water seepage at a rate sufficient to satisfy the intermittent demands of the railway which uses this pump station only as a standby. It cannot be considered demonstrated that a constant demand of 25,000 gallons a day could be furnished at all times by the river.

4. Cost. It is estimated by the Engineering Branch of the Division that the cost of an installation utilizing the Sturgeon River, including a coagulating and filtration plant, would be approximately $\$ 100,000$.

5. Conclusions. The water of the Sturgeon River is of very good quality; the flow may be enough to yield 25,000 gallons a day at all times but such a flow cannot be considered assured. It is therefore recommended that consideration of the use of the Sturgeon as a source of supply be abandoned.

\section{SECTION V--EDMONTON CITY SUPPLY}

1. General. The City of Edmonton obtains its water from the North Saskatchewan River. The municipal water facilities are already loaded to capacity, but the city is willing if necessary to furnish water to the Namao field.

2. Cost. The estimated cost of constructing a suitable pipe line from the field to tap into city mains, according to information of the Engineering Branch of the Division, is $\$ 180,000$. The charge for water furnished would be about 12.5 cents per thousand gallons.

3. Conclusions. Inasmuch as the use of the city supply is the only assured source of potable water at the field and as the rate of delivery of water could be increased in case of emergency or of enlargement of the facilities of the field, it is recommended that immediate steps be taken to tap in to the city mains. It is further recommended (Section III, paragraph 2 above) that the drilling of a well to a depth of about 800 feet to test the deeper ground-water supplies at the field be continued, and in the improbable event of finding comparatively abundant supplies of potable ground-water at this depth, plans for the more expensive connection to the Edmonton supply be abandoned in favor of the well supply. 


\title{
Further Drilling at Namao
}

\author{
By Charles V. Theis \\ 14 January 1944
}

1. The main purpose of drilling the deeper well at Namao was to test the possibilities of obtaining water from local sources before the construction of the water line to Edmonton was so far advanced as to make it infeasible to change plans.

2. In approximately 6 weeks time the drilling has been advanced only about 300 feet on an average of about 7 feet a day. The hole drilled to a depth of 600 feet (No. 3) has been lost and it is now necessary to clean out Well No. 2 from a depth of 380 feet to 507 feet and then to drill ahead in this hole to test the lower formations. Unless drilling can be greatly accelerated, information as to the hydrologic character of the strata below 600 feet will not be available for another month or more, by which time the pipe line will probably be so far advanced as to make it infeasible to abandon it.

3. Certain minor advantages that may accrue from the completion of the drilling at any time are (a) testing the deeper ground-water circulation to throw some light on the question as to whether water can move long distances through these beds without becoming too highly mineralized for use, information which would be of value in determining probabilities of obtaining water elsewhere

in the plains of Aiberta should more military installations be built by the United States and (b) producing information as to the capabilities of deeper aquifers for the use of local inhabitants. It is very doubtful if such advantages can be considered to justify the additional expense of sinking the well, especially as a good test would require careful and conscientious attention to the work which, perhaps because of the conditions of emergency construction, has not been in the previous drilling.

4. Suggestions that the test drilling has not been carefully done are (a) the drilling of Well No. 2 at least 200 feet below the entrance of salt water without noting it; (b) lack of agreement of Wells Nos. 2 and 3 regarding water occurrences in the interval between 300 and 500 feet; (c) the small footage of drilling done; and (d) the collection of a sample of water from Sturgeon River, when that water was being considered as an alternate source of water, that had 7 times the total solid content of either of two check samples collected by others.

5. Recommendation. Further drilling of test wells at Namao will probably not produce information of immediate value in constructing the airfield or of sufficient potential value to justify the cost. It is recommended that previous directives of the Division Engineer requiring the drilling of the well, made in the expectation that the drilling would be sooner completed, be rescinded. 


\section{Water Supply at Namao \\ By Charles V. Theis \\ 24 February 1944}

1. A review of the correspondence and reports dealing with the procurement of the water supply at Namao has been requested.

2. The propriety of the ultimate solution of the water supply problem by connection with the Edmonton water supply cannot be questioned, considering the need for immediate completion of the work, and it is quite improbable that any more feasible solution could have been found even if time had been available for measuring the flow of Sturgeon River during the winter season and drilling and testing deeper wells.

3. The drilling done indicated that the salt water of the Bearpaw shales is much nearer the surface than had previously been expected by those most familiar with the local stratigraphy. The shallow depth of these shales limited the possibilities of obtaining potable water to depths of less than 200 feet or greater than about 600 feet. The water in the upper interval, according to available analyses, is more highly mineralized than elsewhere in the region, especially in sodium sulphate or Glauber's salt, a laxative. The amount of water obtainable from any one of the test wells or any wells in the neighborhood amounted to only a few gallons a minute. The possibility of obtaining a water supply from shallow wells was therefore reduced to the undesirable one of using a large number of wells yielding a poor quality of water.

4. The deeper aquifers of the Belly River formation were not tested because of delays which prolonged the drilling beyond the time that the improbable discovery of water would have done any good. The presence of an adequate supply of potable water in these lower aquifers is improbable because (a) the sands are known to be fine and not very permeable and (b) whatever water is present in these aquifers has originated either by percolation down from the surface locally, in which case its head is small and it has probably been made salty by passing through the overlying Bearpaw shale, or from areas of outcrop of the Belly River near the mountain front near the western boundary of Alberta, in which case the sluggish circulation in these aquifers, presumably like the higher aquifers, has probably resulted in a water of very poor quality.

5. Some fundamental errors in procedure may be noted as a guide to future work.

a. The warning of Major Hake that most of the local rigs were too light and inefficient to drill an adequate test well (Memo 14 July 1943) was disregarded and a month's time thereby lost in drilling.

b. Very little attention was given to the collection of basic data during the drilling. Despite the fact that the collection of data takes some time, and time has been at a premium in most of the construction at Namao and elsewhere, an adequate amount cannot be dispensed with so long as the ultimate decisions are not made immediately on the job. No real pumping test was made at any 
time, bailing tests were inaccurate and not correlated with drawdown, and the water in Well No. 2 was not tested, not to say analyzed. Decisions regarding test drilling in new areas or to untested depths involves the weighing of probabilities and accurate data are necessary to reduce the unknowns as much and as rapidly as possible.

6. One excellent part of the procedure was the employment of an able local geologist, specifically, Dr. Allan of the University of Alberta. The value of geological advice depends first on the ingenuity and judgment of the geologist in applying general geological principles to a particular problem and, second, on a thorough knowledge of the local geology. The latter can be gained in part by a study of existing literature supplemented by field trips and discussions with local geologists. In most cases, especially on emergency work, it will probably be better to employ the man who already has an understanding of the locality. Ideally, the work of the local man should be reviewed by a geologist in whose judgment and knowledge the Division has confidence born of longer acquaintance. It is recommended that the use of local experienced geologists be made a practice. 


\title{
Use of Wells to Dispose of Effluent from the Sewage Treatment
}

\section{Plant at Namao}

\author{
By Charles V. Theis
}

\section{December 1943}

1. As an alternative to disposal of effluent from the sewage treatment plant by surface run off, objection to which has been made by some land owners, or by an expensive covered drain to Sturgeon River, consideration has been given to the use of drainage wells for this purpose.

2. A blanket of glacial clay about 35 feet thick covers the surface at Namao, according to the logs of wells drilled there. This material is as nearly impervious as any widespread deposit on the continent. Only a few percent of the precipitation on the Sturgeon River drainage area and on the drainage area of the North Saskatchewan from Edmonton to Prince Albert has ever run off, and only a part of this run off represents ground-water drainage. Practically all water that falls on the surface is held there until it evaporates or is transpired by vegetation. Not : " ure than a half inch of rainfall, and probably considerably less, percolates beneath the root zone in a year. Although if serious consideration must be given to underground disposal, local tests of permeability should be made; the probability of successful disposal by absorption into superficial deposits at the site is small.

3. The bedrock materials underlying the glacial clay are nearly impermeable dark clay shale and in subordinate amounts, poorly permeable fine silty sandstones and coal. The character of the rocks to a depth of 435 feet is given in the attached $\log$ of Well No. 3, made from drill cuttings by Prof. J.A. Allan of the University of Alberta. When Well No. 3 was at a depth of 85 feet, it produced only 2.2 g.p.m. with a drawdown of about 50 feet. The static level was about 30 feet below the surface. A drainage well of this depth could therefore be expected to absorb under the best conditions a little more than 1 g.p.m. A bailing test made when the well was 130 feet deep yielded only 2.5 g.p.m. with a drawdown of about 100 feet, indicating that the aquifers between 85 and 130 feet were even less permeable than those above 85 feet.

4. Data on the permeability of the few water-yielding beds found at greater depth is less definite. At 250 feet water was bailed from the well at the rate of 5.5 g.p.m. Under the most favorable interpretation this corresponds to about one gallon for each 30 feet of drawdown. At 350 feet, the water above having been sealed off when the well reached this depth, water entered at the rate of about one gallon to 60 feet of drawdown. Up to a depth of 435 feet an additional half-gallon per minute had been picked up.

5. Based on these incomplete records, the writer believes that drainage wells up to 500 feet deep would probably dispose of from two to five gallons of affluent per well per minute. To dispose of the estimated 25 gallons of sewage per minute, from five to 10 wells would probably be required, which might cost from $\$ 25,000$ to $\$ 50,000$. 
6. It is probable that objections, justified or not, would be raised to the drainage of sewage affluent into the aquifers tapped by wells in the neighborhood. These wells are commonly less than 200 feet deep, although a few are deeper. To eliminate or minimize such objections, the wells could be discharged in to the salty water below 250 feet by drilling to a depth below 200 feet, casing and cementing at that depth, and carrying smaller hole to a greater depth.

7. Attention should be given to the possibility of algae or other low forms of life developing in the effluent, coating the walls of the drainage walls, and impeding or preventing absorption.

8. Conclusions and Recommendations

a. If the obviously simpler and less costly method of surface disposal cannot be followed, it will probably be possible to dispose of the sewage effluent by the use of a number of drainage wells, probably about 500 feet deep and costing in all $\$ 25,000$ to $\$ 50,000$.

b. Before such plans are made, however, an infiltration test should be made in the following manner:

(1) Measure and record static water level in Wells No. 2 at several different times; the water level probably varies with atmospheric pressure.

(2) Fill well to point near the surface with clear water; measure and record the amount of water put in, the water level, and the time.

(3) Measure and record the water level at several times while water level falls to 10 or 15 feet below the surface.

(4) Repeat the procedure several times.

(5) Compute the rate of drainage.

(6) Feed water from a tank (protected from freezing) into the well at this rate. Measure water put into well and water level in the well at approximately 12-hour intervals. Continue test for at least a week. 


\section{Sites to be Drilled for Water in the Fairbanks District By Charles V. Theis}

\section{November 1943}

1. The following report is based upon a rapid reconnaisance through the Fairbanks District on November 6 and 7, 1943.

2. Northway Junction Relay Station.

a. General conditions. The sites for both Relay and Repeater Stations at Northway are located on the side of a hill underlain by hard granitic rock. The flood plain of the Tanana River lies about 125 feet vertically below the station and some 750 feet south of it. The bed rock exposed in cuts in the hillside is deeply weathered. The camp is expected to house about 300 men and should have a water supply of about 20,000 gallons a day, or about 15 gallons a minute. Wells in granite and other hard crystalline rocks commonly produce small quantities of water either from weathered zones near the surface of the rock or from joint cracks or other fractures. The chances of obtaining water decrease with depth below the surface and relatively few wells in granite produce as much as $\mathbf{1 5}$ gallons a minute.

b. Log of well being drilled. At the time of my visit to the site, a well being drilled southeast of the Junction of the highway and the access road to the airfield had reached a depth of 55 feet and had the following log according to the driller:

\begin{tabular}{cr}
$\begin{array}{c}\text { Thickness } \\
\text { (feet) }\end{array}$ & $\begin{array}{r}\text { Depth } \\
\text { (feet) }\end{array}$ \\
\hline 3 & 3 \\
12 & 15 \\
1 & 16 \\
8 & 24 \\
3 & 27 \\
28 & 55
\end{tabular}

Loose sand

Rock

Rock with a little water-about

40 gals per hour

Rock

Boulders

Rock 
a. The boulders reported in this log are probably harder parts of the rock in a matrix of somewhat weathered rock. The water found at 16 feet probably represents the approximate base of the thoroughly weathered zone. The drillers reported they were averaging 4 or 5 feet per shift through this rock.

b. Recommendations. Suspend drilling at the present site and drill in the alluvial flats of the valley bottom south of the camp. The site should be far enough from the base of the hill to give a thickness of some 50 or 75 feet of alluvial material above the slope of the bed rock hill as projected beneath the alluvium. This recommendation follows that of Major Hake 24 July 1943. Mr. Van Hoose of Metcalfe-Hamilton-Kansas City Bridge advises, 10 November 1943 , that he has instructed that the drill be moved to a location approximately that recommended above.

3. Dusenberg \#1 Maintenance Camp.

a. General conditions. The camp site is located on a rather broad terrace on the west side of a creek about 4.4 miles northwest of North way Junction. The terrace is approximately 50 feet above the creek level. About 25 men are to be located at the camp, suggesting a water requirement of about 1,750 gallons a day, or a continuous requirement of about 1 gallon a minute. A well at this camp site will probably go through glacial materials that are largely silty and probably frozen for a considerable thickness. Success will probably depend on finding some clean sands or gravels in the materials below creek level and permafrost.

b. Recommendations. A well probably 100 feet deep should be drilled at east side of camp on the terrace some distance away from the hill slopes to avoid bed rock (granite) spurs. Well should be carried to sandy beds and water developed there. If a hidden granitic spur is hit, an attempt should be made to develop the necessary small amount of water in the upper weathered part of the bed rock. If wells are a failure, the hauling of water from Northway Relay for the small group of men would not be too serious a problem.

\section{Midway Lake Maintenance Camp.}

a. General conditions. The camp here is located on a terrace and terrace slope about 50 feet from the level of Midway Lake. A few exposures through the snow show fine silts. The camp lies between two bed rock (granitic) spurs, one lying southeast of the culvert at the southeast end of the camp and one lying northwest of the culvert at the northwest end of the camp. Provisions are to be made for about 25 men at the camp, indicating a water requirement of about 1,750 gallons a day, or about one gallon a minute. The exposed materials underlying the camp site are too fine to furnish large quantities of water, but it seems probable that some sandy beds may be struck which will yield the small quantity of water needed for the camp. It seems probable that some of the material is frozen.

b. Recommendations. Drill well, probably 100 feet deep, near southeast end of camp site, but within an area lying between the road and the lake and extending not more than approximately 200 feet along the road northwest of the culvert near the southeast end of the camp site. The meat pit near the old garage is as favorable a well site as any. Discontinue drilling when requisite water is obtained as large quantities of water cannot be expected. If buried bed rock is struck below frost level, drill through the decomposed part as water 
may be found near the base of the decomposed zone but do not drill into solid unweathered rock for more than 20 or 30 feet.

5. Eastern Engineering Camp.

a. General conditions. The camp is located about 90 feet above Robertson River on a small terrace on the south bank of the river. Where exposed, the materials under the terrace are poorly sorted, rather silty, gravel and boulders. On the north bank of the river a higher terrace is underlain by silty materials with little gravel; similar material may underlie the camp site at depth. The camp will probably require only 2,000 gallons of water a day. A well drilled in the present camp away from the hills back from the camp will probably obtain water at about river level.

b. Recommendations. Drill a well at convenient location in camp, as near the river as possible, somewhat over 100 feet deep.

6. Petersen Maintenance Camp.

a. General conditions. The camp is on a terrace on the south side of Johnson River about 40 feet above river. Boulders and gravel are exposed in the upper part of this terrace but the lower part was not seen. The higher terrace on the opposite side of the river is underlain by silt with a few boulders and pebbles; this material may underlie the Petersen Camp at depth. The water requirement is expected to be around 1 gallon a minute, or some 2,000 gallons a day.

b. Recommendations. A well drilled to a depth somewhat below river level any place in the present camp will probably provide sufficient water for the camp. 


\section{Ground-Water Conditions at Fort Nelson Airport \\ By Charles V. Theis}

7 December 1943

1. The conditions obtained during the drilling of the wells at Ft. Nelson Airport have been described in various memorandums. Both wells were drilled with rotary equipment, and certain phenomena were obscured by the drilling mud. Both start at about 1,170 feet above sea level and about 270 feet above Nuskwa and Ft. Nelson rivers. Both went through clay and the glacial deposits and struck gravel also of glacial origin at about 672 feet. This gravel persisted to the bottom of Well No. 2 at 706 feet and to 725 feet in Well No. 1. Well No. 2 continued through black shale and fine sandstone to 1,451 feet. A show of gas was found at 1,010 feet, according to the drillers, as reported by Major Hake, and a flow of gas at 1,450 feet according to other reports.

2. The sequence of events in drilling Well No. 1 was as follows:

a. A 12-1/2 inch (?) hole was drilled to 150 feet, cased with 10-3/4-inch O.D. casing and cemented.

b. A 9-inch (?) hole was drilled to 925 feet, mudding off and missing the water at 700 feet, and perhaps elsewhere (April 6).

c. An unsuccessful attempt was made by the driller to set a plug in the gravel stratum (April 9).

d. The hole was drilled to 1,450 feet (April 13).

e. A cement plug was installed in the well by the driller, supposedly at 730 feet, but actually apparently with its top at 749 . Nine-inch casing with the lower 80 feet perforated was placed in the well.

f. The well was swabbed for 24 hours and produced neither gas nor water (April 16).

g. After swabbing for another 24 hours or less, both gas and water were brought into the well simultaneously (April 17).

h. The perforated casing was withdrawn from the well and an attempt made under Major Hake's directions to run blank casing in the well to see if the gas were leaking past the plug. The casing could not be reinserted, and the attempt was unsuccessful (April 24).

i. The hole was reamed out and cleaned and 7-inch casing reinserted in the hole to a depth of 730 feet. The casing was blank from 730 to 690 feet and perforated from 690 to 610 feet. 
j. The hole was again swabbed for 2 hours at the rate of 85 g.p.m. and produced gas at the rate of 15,000 cubic feet per day (April 27).

k. Under direction of Captain (then 1st Lieutenant) Patterson of 331st Engineers, the hole was cleaned out to a bridge at 745 feet and a new cement plug placed to 720 feet in several pourings (May 27).

1. The well was swabbed under direction of Capt. Patterson at the rate of about 30,000 gallons per day and produced no gas (May 28 - June 3).

m. Some time later, the well began producing gas again. When pumped the water was silty owing presumably to the erosion of clay exposed through the upper perforations in the casing in the interval 610 to 672 feet.

3. The sequence of events in drilling Well No. 2 was as follows:

a. A 12-1/2-inch hole was drilled to 150 feet; 10-3/4-inch O.D. casing set and cemented, the cement plug rising to 141 (July 8).

b. Plug was drilled out and 9-inch hole drilled to 697 feet, coring at intervals below 485 to 678 feet (August 6).

c. Hole washed; 7 -inch O.D. blank casing set at 680 feet. Cemented casing; cement from 684 to 678 feet (August 7).

d. Drilled plug and carried hole to 706 feet (August 10).

e. Swabbed well August 11; no gas observed.

f. Air jetted; well; no gas observed.

g. Bottom of well at 677 feet (August 17).

4. Well No. 2 was equipped with a Layne pump, driven by a Diesel unit, at the time of the writer's visit on October 29. The pump was set at 359 feet and the water level was at 250 feet according to report. The well was completely sealed at the top and no check measurements could be made. Measurements made by timing the input into the settling tanks showed the well to be producing 65 g.p.m. at that time. The water is clear, has a straw color, and is accompanied by inflammable, odorless gas, presumably methane.

5. Inasmuch as the presence of gas forms a fire hazard and should be eliminated if possible, a determination of its sources is of some importance. It has been commonly ascribed to leakage past the plug in Well No. 1 followed by dissemination into the aquifer and into Well No. 2.

6. The writer believes that the gas is dissolved in the water of the 700-foot aquifer for the following reasons:

a. Gas continues to be evolved from a sample of the water hold in a glass in the same manner as $\mathrm{CO}^{2}$ is evolved from soda. At least some of the gas is dissolved in the water. 
b. Gas and water came simultaneously into Well No. 1 when it was being swabbed.

c. It is difficult to conceive of gas rising past the plug in Well No. 1, and then instead of continuing its free course up the well, disseminating in to the aquifer. The water level rose in Well No. 1 after the cement plug was put in and hence any gas-laden water that might be present at depth could not force its way in to the 700 -foot aquifer.

d. Gas rising as free gas from depth in Well No. 1 could probably not be drawn through the pores of the aquifer in the presence of water.

e. The amount of methane that could be dissolved in water at the temperature and pressure obtained in the aquifer is about 1.15 volumes (at normal atmospheric pressure) to 1 volume of water. The gas that would escape when swabbing 60 gallons of water a minute would be about 18,000 cubic feet a day. Estimates of the flow of gas according to Major Hake varied from 10,000 to 36,000 cubic feet a day. Lt. Col. Griffin used 15,000 cubic feet a day as the probable production.

f. Methane, or marsh gas, is evolved under conditions that inhibit rapid oxidation of vegetable matter and is found in many places in ground water. In the San Luis Valley of Colorado, for instance, the artesian water near the center of the basin is straw-colored or brown and evolves methane in sufficient quantity that in places it is collected at the head of the water well and used for heating small dwellings. The straw color of the water at Ft. Nelson is probably indicative of passage through peaty deposits, buried by the streams that furnished the gravel and a potential source of methane.

g. The observations that led Major Hake to consider, before Well No. 2 was drilled, that the gas rose from greater depth--are valid also for believing that the gas is dissolved under pressure in the water. These are (aside from the show of gas is dissolved under pressure in the water considered a supplementary source of gas that was probably plugged off by the cement in the well) : that when the hole was open, except for mud and water to 650 feet, no gas appeared; that when mud was being circulated, no gas appeared; and that gas followed the swab to the surface. If the gas is dissolved in the water, it would not be evolved in appreciable quantity when the well was full of drilling fluid, and particularly when drilling fluid was being circulated under pressure; and it would be evolved whenever the pressure was reduced by swabbing or pumping.

h. The observations of Captain Patterson that no gas was present when No. 1 well was swabbed for several days after he had set the cement plug and not in No. 2 during its swabbing are to be explained either by (1) the assumption that the methane is contained in more or less irregular pockets, which is a probable geologic occurrence, or (2) that the conditions of swabbing dissipated the gas so it was not observed. Swabbing causes a wide fluctuation of water level, so that on the downstroke, air is drawn into the well casing to be mixed with gas that evolves on the upstroke. The lack of gas during swabbing is the only phenomenon that is not readily explained by the hypothesis that the gas is dissolved in the water. The gas would evolve somewhat slowly from the entire surface of the water swabbed out and could escape easily into the air, especially in a breeze. 
7. It is evident that both wells are very inadequately finished as water wells. In Well No. 1, blank casing lies opposite the gravel aquifer from 690 feet to the bottom of the hole, and perforations are present opposite the aquifer only from 672 to 690 . Perforations exist opposite clay from 610 to 690 . In Well No. 2, the only means of entry of water is through at least 7 feet of gravel lodged in the bottom of the blank 7-inch casing.

8. In order to provide additional water or standby capacity at the airfield, two alternative procedures may be followed. The first is to rehabilitate Well No. 1. This will be a delicate and difficult procedure, requiring expert drilling techniques; might not be successful even under the best conditions; and would still yield gas-laden water. The rehabilitation would involve the following steps. The exact procedure could be worked out with the drilling superintendent.

a. Clean out well to the top of the cement plug.

b. Perforate the casing between 690 and 720 feet.

c. Prepare 120 feet of liner of size just small enough to go into present casing. The lower part of the liner, over a length extending from the cement plug to the top of the aquifer, should have large holes cut into it, leaving just enough metal to support the rest of the liner, which should be left blank. The liner should be lowered into the hole and seated on the cement plug.

d. Lead packer should be firmly placed in the annular space between upper part of liner and casing.

e. One or two feet of cement should be placed in the bottom of the liner to steady it at the bottom.

f. This procedure is intended to allow the entrance of water through the lower part of the casing, and to prevent the flow of water past the open perforations opposite the clay. If the clay is sufficiently plastic, it might still squeeze through the perforations and work its way between casing and liner to the flowing water lower down.

9. The second possible procedure to develop additional water is by drilling a new well. In the opinion of the writer, the presence of water between 250 and 500 feet of better quality than the present supply is probable for the following reasons: 
a. The log of Well. No. 1 records the following strata in this interval:

\begin{tabular}{lrrr} 
& Thickness & From & To \\
\cline { 2 - 3 } Clay with gravel bands & 29 & 228 & 257 \\
Sandstone & 8 & 257 & 265 \\
Boulders and gravel & 5 & 265 & 270 \\
Sandstone & 20 & 270 & 290 \\
Boulders & 2 & 290 & 292 \\
Clay and gravel & 48 & 292 & 340 \\
Clay & 60 & 340 & 400 \\
Clay and gravel & 10 & 400 & 410 \\
Clay & 20 & 410 & 430 \\
Gravel & 20 & 430 & 450 \\
Fine gravel and sand & 50 & 450 & 500
\end{tabular}

The log of Well No. 2 shows:

\begin{tabular}{lrrrr} 
& Thickness & & From & To \\
\cline { 2 - 3 } Gravel and clay & 20 & 217 & 237 \\
Gravel and boulders & 13 & 237 & 250 \\
Coarse sand and gravel & 190 & 250 & 440 \\
Gravel & 40 & 440 & 480 \\
Plastic clay & 194 & 480 & 674
\end{tabular}

b. Both logs show significant thicknesses of coarse sediments in the interval between 250 and 500 feet.

c. Water level from the 700 -foot aquifer stands at 250 feet and river level is at about 270 feet. It is probable that all the sediments are saturated below this approximate level. 
d. If porous sediments are present in this interval, it is probable that groundwater circulation is more vigorous at this level and more freely connected with surface streams than at the 700 -foot level which is separated by about 200 feet of clay from the surface drainage. More vigorous ground-water circulation probably would result in better water.

e. No water was recorded in this interval by the drillers. However, water was not recorded in the 700 -foot aquifer, and the water was so effectively sealed by the drilling that much swabbing was required to bring it in. Considering the record of the drillers, the fact that water was not noted does not prove it was not present.

10. Conclusions

a. In all probability, most of the gas in the wells is dissolved in the water itself and further attempts to plug off the lower strata in Well No. 1 are needless.

b. Well No. 2 is furnishing the required water supply and will probably continue to do so, but it is possible that the gravel plug in the blank casing may rise or become plugged itself with fine sand or silt and shut off the water.

c. Rehabilitation of Well. No. 1 will require a delicate, probably expensive, and possibly unsuccessful procedure to clear the water.

d. There is probably water-bearing material at a depth of 250 to 500 feet at the site which will probably yield water of better quality and free of gas.

\section{Recommendations}

For a standby well and probably as prime source of water at the camp, drill with cable tools a third well, carefully testing for quality and quantity of water encountered between 250 and 500 feet. If water is not found in this interval, continue to the gas-bearing water at 700 feet. A very careful log should be kept and the casing perforated in place opposite water-bearing materials. 


\section{Water Supplies for Relay and Repeater Stations on the Alaska Highway}

By Charles V. Theis

23 December 1943

\section{SECTION I--General Remarks}

1. In the region along the Alaska Highway, well water is, in general, difficult to procure. Recharge of the ground water is of small amount because of the nearly impermeable blanket of glacial till over considerable areas of low uplands and mountain valleys, of residual soils in a large part of the area developed from black shale, and because of permafrost conditions in the northern part of the area. It seems probable from records of streams in the areas underlain by glacial till and black shale around Edmonton that less than 1/4 inch per year of precipitation is ever able to go underground in the region traversed by the Alaska Highway.

2. The chance of obtaining adequate wells is also diminished by the poorly permeable character of the rocks in much of the area. From Dawson Creek to about 50 miles north of Nelson, the country is, in general, underlain by black shales which yield little water to wells. Some silty sandstones are interbedded in these shales, but they are apparently irregular in their occurrence, minor in amount, and their positions cannot be determined without considerable geologic study. In the area from Ft. Nelson north, the bedrocks are of nearly every variety, from impermeable to poorly permeable, and in a few localities perhaps quite permeable. They are generally covered along the Highway from Ft. Nelson to the Tanana Valley by the deposits of valley glaciers, which range from nearly impermeable to quite permeable, and whose composition at depth cannot usually be determined in advance of the drill. In the Tanana Valley, conditions for obtaining wells are favorable in general, but even here permafrost and the deposits of fine silt dropped by the stream cause locally anomalous conditions.

3. It is apparent that in order to provide water supplies at already fixed localities, considerable prospecting by the drill must be done. In some localities careful geological work might result in finding some places where shallow water might be developed from springs or infiltration galleries, but, in general, the possibility of shallow supplies failing in cold weather and the high cost of laying pipe lines protected from freezing from such water points to the camps indicate that test drilling for deeper water is to be preferred.

4. Most of the material to be drilled can be handled by moderate-sized cable tool rigs without much difficulty, although some boulder clays and boulder beds may cause some trouble. Rotary rigs would probably miss the weak flows likely to be encountered in many of the wells.

5. The following table summarizes the data on the water supplies. Further data are given in Section II of this memorandum. 
Water
Req'd

Thousands

of

Location

Gallons

per Day

1. Dawson Creek Base

2. Fort St. John

3. Blueberry

4. Trutch

5. Fort Nelson

6. Summit

7. Muncho

8. Coal River

9. Watson Lake

10. Swift River

11. Brooks Brook (Repeater)

12. Johnson Crossing (Relay)

13. McCrae Base

14. Canyon

15. Destruction Bay

16. Koidern (Repeater)

17. Koidern (Relay)

18. Northway Junction

19. Cathedral Bluffs

20. Big Delta

21. Fairbanks Base

70

7

20

20

7

20

7

25

7

3

18

70

16

3

3

7

30

7

20

70
7 Probably

Provided

Prospects

of

Depth of

for?

Well Water (Feet)

\section{Yes}

Yes

No

Poor

500

No
Yes
Yes

Probably

No

Fair

300

No

Good

100

Good

100

No

Fair

250

No

Fair

400

7 No

Fair

100

No

Good

150

\section{Yes}

Yes

No

Yes

Yes

Yes 


\section{SECTION II -- Individual Localities}

1. Dawson Creek Base Installation. Now provided with supply from Kiskatinaw River (Cutbank River).

2. Fort St. John. 100 men; water required 7,000 GPD. System installed using water from Charlie Lake.

3. Blueberry Relay Station, J-53. 280 men; water required 20,000 GPD.

a. General Conditions. Station is located on high ridge underlain by shale and silty sandstone. Probabilities of obtaining good well are very small. Well 178 feet deep produced only 1,400 GPD and one 100 feet deep has dried up. No surface supplies available.

b. Recommendation. Drill test well at site up to 500 feet deep. If this produces as much as 5 GPM, drill other wells at 250-foot centers to get requisite supply. If not, following Hake's suggestion, drill well to bedrock in bottom of valley about $1 / 2$ mile northeast of camp, probably less than 100 feet deep to try out possibilities; not regarded as hopeful. If neither locality produces enough water, only alternative seems to be to haul.

4. Trutch Relay Station, J-157. 100 men; 7,000 GPD.

a. General Conditions. This station is also located on a ridge underlain by black shale, perhaps including some sandstone. A well 206 feet deep at the camp is reported to be all in shale, to have pumped 5 gallons a minute for 12 hours.

b. Recommendation Further activity at this station can be deferred until needs of other camps are satisfied if the reported production holds up. If the well should fail, it should be deepened to 500 feet if necessary; if it will furnish a partial but insufficient supply, a supplementary well should be drilled. The supplementary well may be drilled at the most convenient location, not necessarily near the present, inconveniently located well.

5. Fort Nelson Relay Station, N-O. 280 men; 20,000 GPD required.

a. General Conditions. Situated about 450 feet above Muskwa River and underlain probably by black shale. Prospects that the old buried channel from which the airport derives water is anywhere in the vicinity of the relay station are poor. Prospects of obtaining adequate quantities of water in the bedrock are also poor, but because the water-bearing characteristics of these rocks are unknown and alternative supplies are expensive, a test well is justified.

b. Recommendation. Drill a test well 100 feet below river level, say 600 feet. If well yields 5 GPM or more, drill supplementary wells at 250 -foot centers. If well is a failure, surface water supply from Muskwa River about 1-1/2 miles distant is an alternative. 
6. Summit Lake Relay Station; N-102. 100 men; 7,000 GPD.

a. General Conditions. Camp situated on a glacial moraine, composed of boulder clay, damming the lake. Well drilled with inadequate rig had been drilled to 21 feet when the rig broke down. Camp now obtaining water from stream draining the lake. Plans have been made by the Commanding Officer to run pump shack over the ice on the lake this winter, pumping through a hole in the ice, and immediately draining the intake line after pumping.

b. Recommendation. Use Summit Lake as source of water; provide permanent intake facilities.

7. Muncho Lake Relay Station, N-172. 280 men; 20,000 GPD required.

a. General Conditions. Station is on an alluvial fan yielding several second-feet of water at its base near Muncho Lake. Well at power house in U.S.E.D. camp reported to be 68 feet deep, to have water level 28 feet from surface, and to have pumped 7 GPM for 24 hours. Probable that well will yield required water with proper pump.

b. Recommendation. Make pumping test to determine if well will make requisite $20 \mathrm{GPM}$; if not, drill deeper.

8. Coal River Relay Station, N-260. 100 men, 7,000 GPD required.

a. General Conditions. Situated on a terrace about 150 feet above Liard River, probably underlain by alluvial sand and clay. Impermeable bedrock spurs project beneath terrace across river about 1,000 feet up-river from center of camp and an equal distance down-river. Since our visit, well is reported to have been drilled 70 feet deep, water standing 40 feet from surface; bailed 15 GPM for unspecified time. If data are correct, water is standing 100 feet above river $1 / 2$ mile away.

b. Recommendation. Watch performance of well carefully and if it should fail, deepen it to 300 feet if necessary unless bedrock is found at shallow depth. In this case drill another well about 1,000 feet from present well and on direct line between the present well and the river, avoiding vicinity of bedrock spurs crossing river.

9. Watson Lake Relay Station, N-352. 350 men; 25,000 GPD required.

a. General Conditions. Station is situated about 50 feet above Watson Lake and about 300 feet above the Liard River. It is underlain by glacial materials of unknown thickness and character. A well dug and drilled at the repeater station, reported 50 feet deep, is reported to have been pumped for 3 days by the drillers but no further pumping has been done and no accurate record of what the well produced has been made. Present plans call for digging a shallow well near a small lake about 1,200 feet from camp.

b. Recommendation. Present plan should be carried through by digging a test at least 15 feet below the lake surface to see if sufficient permeable material to supply the well is found. If the lake freezes solid and considerable thickness of permeable beds below lake level are not present, a test well up to 300 feet deep should be drilled at a convenient location. 
10. Swift River Relay Station, N-456. 100 men; 7,000 GPD required.

a. General Conditions. Station is located only about 20 feet above Swift River on an alluvial fan. Probabilities are that abundant ground water can be found at any location in camp. A spring flowing several hundred gallons a minute is present same distance behind the repeater station. Present plans call for tapping Swift River.

b. Recommendation. Dig a well to about the level of Swift River in the north part of the camp or if convenient drill one up to 100 feet deep. In the event of failure, utilize Swift River directly.

11. Brooks Brook Repeater Station, N-556. 50 men; 3,500 GPD required.

a. General Conditions. Located at mouth of creek only a little above level of Teslin Lake, probably underlain by fan gravel. Plans call for drilling well near Brooks Brook, which will probably be successful.

b. Recommendation. Proceed as planned.

12. Brooks Brook Relay Station at Johnson's Crossing. 250 men; 18,000 GPD required.

a. General Conditions. Camp lies about 200 feet above Teslin River and is underlain by glacial clay, perhaps with interbedded porous materials and perhaps very much disturbed and irregular because of landsliding.

b. Recommendation. Well up to 250 feet deep will probably encounter water. Drill such a well or pump from the river about 750 feet distant, whichever is most feasible.

13. McCrae Base Installation, N-639. 1,000 men; 70,000 GPD required.

a. General Conditions. Camp lies near point where glacial lake clays of Lewes River and other glacial deposits lap against sides of bedrock valley of Lewes River and about 300 feet above that stream. Four wells from 53 to 297 feet deep have been drilled into bedrock, consisting of volcanic rock, shale and limestone; total production of three of these reported to be 90 GPM; that of fourth well unknown. Static water level reported to be from 225 to 300 feet above river. The data are either inaccurate in major features or very unusual ground-water conditions exist, involving damming of ground water by the glacial deposits in the river.

b. Recommendation. Thorough supervised pumping tests of the wells should be made to get conclusive data. If these check production figures, present wells will furnish supply. If not, well at Tire and Battery Shop should be deepened to about 400 feet to test water-bearing conditions at and below local drainage level, and, if a surface supply is preferred, the creek now furnishing water for the camp, which is reported to have flowed 100 GPM in March, may be used. 
14. Canyon Relay Station, WH-89. 100 men; 7,000 GPD required.

a. General Conditions. Camp is situated about 25 feet above level of Canyon Creek (Aishihik River). Hard, impervious crystalline rocks are present just west of the station at the crossing of the river. Present plans call for a well near the west edge of camp.

b. Recommendation. Proceed with plans to drill well; if gravels are found to extend to creek level before reaching bedrock, the well should yield an abundance of water. If well is a failure, use water from Canyon Creek.

15. Destruction Bay Relay Station, WH-183. 230 men; 16,000 GPD required.

a. General Conditions. Camp located about 30 feet above Kluane Lake probably underlain by boulder clay with interbedded permeable materials.

b. Recommendation. Proceed with present plans to drill well in camp; well 40 to 150 feet deep should find water rising to lake level. Water that may be found in gravel at surface should be sealed off. If well is failure, use water from Kluane Lake.

16. Koidern River Repeater Station, WH-277. 50 men; 3,500 GPD required.

a. General Conditions. Near bank of Koidern River in large swamp. Well, drilled since our visit, reported to have obtained water after drilling through permafrost to a depth of at least 35 feet.

b. Recommendation. Check quality of water and make pumping test to ensure that the small quantity of water required is available.

17. Koidern River Relay Station. 100 men; 7,000 GPD required.

a. General Conditions. Situated on edge of alluvial fan of White River about 50 feet above level of river. Well has been drilled 74 feet deep, obtaining water in sand and gravel. Static water level at 35 feet, well reported to have bailed 30,000 gallons in 24 hours.

b. Recommendations. Present well appears to be entirely satisfactory.

18. Northway Junction Relay Station, WH-379. 400 men, 30,000 GPD required.

a. General Conditions. Station is located about 125 feet above Tanana River on side of hill underlain by granitic rocks. Well had been drilled about 60 feet into granite at time of visit, but hole was later abandoned and rig moved to flood plain of Tanana River, approximately in conformity with following recommendation.

b. Recommendation. Drill test well in the meander of the River south of the intersection of the Highway and Airport Road and in the next down-stream loop closer to the repeater station. For moderate assurance of getting water in gravel or sand above the bed rock, the well in either case should be about 2,000 feet from the Highway. Best procedure will be to drill present well until water is secured or solid bed-rock entered 5 feet; if unsuccessful drill at least 1,000 feet from foot of bluff or design system using water from Tanana directly. 
19. Cathedral Bluffs Relay Station, WH 468. 100 men; 7,000 GPD required.

a. General Conditions. Station is located in alluvial fan near Tanana River. Two wells approximately 50 feet deep with water level about 38 feet below original ground level have been drilled and they will probably produce an abundance of water. However, water occurs in part between 2 layers of permafrost and performance should be noted carefully during winter.

b. Recommendation. None, unless wells should fail during winter, in which case deepen them.

20. Big Delta Relay Station, WH-557. 280 men; 20,000 GPD required.

a. General conditions. Station is located about 20 feet above Big Delta River and underlain by alluvial deposits. Two wells 95 and 100 feet deep at Relay and Repeater Stations have been drilled. No permafrost was found.

b. Recommendation. No trouble is anticipated with the present wells.

21. Fairbanks Base Installation, WH-651.

a. General Conditions. Situated in Tanana Valley and underlain by alluvial gravels. Well No. 1 is 40 feet deep, static water level 4.3 feet from surface, pumped 265 GPM for 24 hours with a drawdown of 7.5 feet; no permafrost. Well No. 2 is 88.5 feet deep; static water level 4.0 feet from surface, pumped 265 GPM for 24 hours with a drawdown of 8.0 feet; permafrost from 43 to 64 feet.

b. Recommendations. No trouble is anticipated with present wells. 


\title{
Water Supplies for Maintenance Stations in the Dawson Creek District
}

\author{
By Charles V. Theis
}

30 December 1943

General Remarks

1. Generalizations concerning ground-water suppplies in the Dawson Creek District as well as elsewhere along the Alaska Highway have been given in a memorandum on water supplies for relay stations dated 23 December. Briefly, it appears that there is probably only a sluggish circulation of ground water in the area, that the bedrocks from $\mathrm{Ft}$. Nelson south are in general poorly permeable but contain a few aquifers that have produced a few gallons per minute of water, that the presence or position of such aquifers can generally not be determined, at least in the time available, and that, especially from Ft. Nelson north, the materials along the road from which water will be derived are of glacial age, differing greatly--and, in the absence of detailed knowledge, apparently erratically--in permeability.

2. From the nature of the case, much of the drilling to be done will be of the nature of test drilling and probably some of the wells will be failures. To ensure that the testing will be done carefully, it will be advisable that it be done under the observation of a man with geological and ground-water training, who will make necessary observations on the character of drill cuttings and of water levels and other phenomena during pumping tests.

3. Despite the doubt that must be entertained as to the success of wells in many localities, it is believed that test drilling is justified in nearly all cases because of the convenience of a well and its relatively low cost as compared to that of deeply buried pipe lines to known but relatively distant sources and to that of hauling water.

4. Summary. Pertinent facts and judgments regarding water supplies for the maintenance camps are summarized below. Further discussions of individual supplies are given in the following section. 


\begin{tabular}{|c|c|c|c|c|}
\hline $\begin{array}{l}\text { Maintenance } \\
\text { Camp }\end{array}$ & $\begin{array}{l}\text { Water } \\
\text { Required } \\
\text { Thousands } \\
\text { of g.p.d. }\end{array}$ & $\begin{array}{c}\text { Chance of } \\
\text { Obtaining } \\
\text { Water }\end{array}$ & $\begin{array}{l}\text { Approximate } \\
\text { depth of } \\
\text { test well (ft.) }\end{array}$ & Remarks \\
\hline $\mathrm{D}-20$ & 3 & Good & 200 & \\
\hline $\mathrm{J}-0$ & 7 & -- & - & Supply already provided. \\
\hline $\mathrm{J}-45$ & 3 & -- & -- & Supply already provided. \\
\hline $\mathrm{J}-88$ & 3 & Fair & 200 & \\
\hline $\mathrm{J}-117$ & 3 & -- & - & Supply already provided. \\
\hline $\mathrm{J}-165$ & 2 & Good & 150 & \\
\hline $\mathrm{J}-201$ & 2 & Good & 125 & \\
\hline $\mathrm{J}-235$ & 2 & Fair & 175 & \\
\hline $\mathrm{N}-8$ & 7 & Poor & 400 & $\begin{array}{l}\text { Geologic study should be } \\
\text { made as to possibility of } \\
\text { obtaining water in valley } \\
\text { to south. }\end{array}$ \\
\hline N-51 & 3 & Poor & 400 & Geologic study needed. \\
\hline N-85 & 3 & - & -- & Supply already provided. \\
\hline N-138 & 3 & Moderate & 100 & $\begin{array}{l}\text { Supply also available from } \\
\text { creek or possibly dug well } \\
\text { southwest of camp. }\end{array}$ \\
\hline N-176 & 3 & Very good & 50 & $\begin{array}{l}\text { Supply also available from } \\
\text { Muncho Lake. }\end{array}$ \\
\hline N-213 & 7 & Good & 125 & $\begin{array}{l}60 \text { feet of hole already } \\
\text { drilled. }\end{array}$ \\
\hline $\mathrm{N}-260$ & 3 & -- & -- & $\begin{array}{l}\text { Supply probably already } \\
\text { provided but well should be } \\
\text { tested. }\end{array}$ \\
\hline N-313 & 3 & Moderate & 300 & $\begin{array}{l}\text { Ground-water conditions } \\
\text { largely unknown. Further } \\
\text { study available. }\end{array}$ \\
\hline
\end{tabular}

Individual Localities

5. D-20: 50 men, 3,500 g.p.d. required.

a. General Conditions. Situated on a bench about 200 feet above the Cutbank or Kiskatinaw River. Glacial deposits blanket the vicinity. On the bank of the river at the road crossing $3 / 4$ mile from the camp about 50 feet of fine- and medium-grained sandstone is exposed just above river level. At present the camp is hauling water from Dawson Creek. 
b. Recommendation. A well drilled into the bedrock at the camp about 200 feet deep will probably yield the requisite supply.

6. J-0: $100 \mathrm{men} ; 7,000$ g.p.d. required.

a. General Conditions. Three wells are in existence at the old camps of the P.R.A., R. Melville Smith Co., and Okes. Those at P.R.A. and Smith's are 262 feet deep and that at Okes, 180 feet. The Okes well is reported to have been in black shale its entire depth and it is probable that the other deeper wells were also, except perhaps for some thin sandstones that are not apparent in exposures in the neighborhood. The P.R.A. well is reported to have pumped 15 g.p.m. for 8 hours and the Okes well 20 g.p.m. Water level in the Okes well is reported to be at 140 feet.

b. Recommendation. The vicinity of the camp is supplied with the requisite water and no further action appears to be necessary.

7. J-45: About 50 men; 3,500 g.p.d. required.

a. General Conditions. Located on a ridge between Blueberry and Cameron Rivers. Well drilled in July 1942 reported to be 185 feet deep, to have passed through 90 feet of glacial clay and to have been in shale from there to the bottom of the well, and to have pumped 5 g.p.m. for 3 days. Water level reported at 115 feet. Well was pumping about 5 g.p.m. when visited October 26.

b. Recommendation. Camp appears to be adequately supplied with water.

8. J-88: 50 men; 3,500 g.p.d. required.

a. General Conditions. On high ground several hundred feet above main drainage lines. Underlain by black shale with some sandstone beds exposed in shallow road cuts. At present hauling water from a camp at J-95 where a well 105 feet deep in shale and sandstone obtains about 5 g.p.m.; water level reported to be at 78 feet.

b. Recommendation. It appears probable that water will be obtained by a well about 200 feet deep at $J-88$.

9. J-117: 40 men; 3,000 g.p.d. required.

a. General Conditions. Situated about 300 feet above the level of the Sikanni Chief River, and about 1.2 miles north of the river. Wavy bedded sandstone outcrops from a little above water level in the Sikanni to perhaps 100 feet above it. A well in the camp 380 feet deep, with water level at 216 feet, reported to be entirely in soft shale, but it is probable that some soft sandstone such as that seen on the Sikanni is present. It was pumping about 15 g.p.m. when visited. The well furnished water for several of the surrounding camps during the construction season.

b. Recommendation. The well seems more than adequate to supply the camp. 
10. J-165: 32 men; 2,000 g.p.d. required.

a. General Conditions. Situated on a broad terrace underlain by glacial till and probably some permeable sands and gravels about 100 feet above local drainage level. The camp at present hauls water from a spring at J-179, which issues from a gravel bed about 25 feet below the general level of the country and about 75 feet above the bottom of a small valley not far from Prophet River. The spring flows about 10 g.p.m. into a 500-gallon tank from which water is pumped into the tank wagons. Reports vary as to its permanence during the winter.

b. Recommendation. A well less than $\mathbf{1 5 0}$ feet deep will probably yield sufficient water for the camp. Temporarily some expedients will probably be needed to winterize the spring now being used. A well about 25 feet deep dug or augered on the level land above the spring would probably reach the horizon feeding the spring. Alternately, 2-inch pipes about 10 feet long could be driven horizontally into the beds feeding the spring and made to discharge into a heated spring house.

11. J-201: Probably 2,000 g.p.d. required.

a. General Conditions. The camp is situated not far from the Prophet River and, from aneroid observation, around 100 feet above it. The underlying materials appear to be glacial sands and clay, underlain by glacial till. The camp when visited October 28 was hauling water from a short springbed stream at J-192. The springs emerge in several pools below a gravel bluff about 25 feet high and about 400 feet east of the road. The flow was about 50 g.p.m. when visited. The branch heading in the springs was diverted at the roadside into a spring box from which water was pumped into the tank wagon.

b. Recommendation. Drill test well at camp for a permanent supply which may find water at the base of gravelly deposits overlying the boulder clay or perhaps in porous beds within the clay at depth of less than 125 feet. To utilize the spring during the winter it will probably be necessary to drive 2-inch pipes about 10 feet long horizontally into the hillside to tap the bed feeding the spring. A well-insulated water line would be necessary to carry the water about 400 feet on about a $5 \%$ grade to the roadside.

12. J-235: About 18 men; 1,500 g.p.d. required.

a. General Conditions. Camp is situated about 175 feet above Jackfish Creek and about 0.5 mile north of it. It is underlain by a cover of boulder clay, probably thin, and by black shale and a few thin beds of sandy shale as exposed on the banks of Jackfish Creek. The camp when visited October 28 was hauling water from a shallow well or sump about 3 feet deep dug in a gravel pit about 10 feet deep near the Prophet River about 1 mile west of the highway at J-226. The water level in the well is reported to be at the level of the river.

b. Recommendation. The small supply of water necessary can probably be obtained from a well drilled to about the level of Jackfish Creek or about 175 feet. Temporary measures for winter include deepening the well from which water is hauled below frost level and probably putting in woodstove pipe as a casing, filling in around it, extending the pipe above the ground and banking around it with fine-textured dirt. 
13. N-8: 100 men; 7,000 g.p.d. required.

a. General Conditions. The camp is situated about 500 feet above Muskwa and Ft. Nelson Rivers. It is underlain almost from the surface by black shales that are exposed at the edge of the P.R.A. camp at N-8 for about 100 feet above the level of the camp and were apparently penetrated in the well at the P.R.A. camp for a depth of 165 feet. The U.S.E.D. camp at N-8 hauls water from Pouce Coupe Creek which passes through the P.R.A. camp, and the P.R.A. camp pumped water from the creek. The creek freezes in winter, leaving the camps without a local water supply. At the P.R.A. camp, neither a dug well about 20 feet deep nor a well drilled to a depth of 165 feet yielded sufficient water. A valley apparently overwide for the stream it contains lies to the south of the camp. It is possible that this valley is deeply filled by glacial materials and might contain some porous beds with water.

b. Recommendation. Further geological study should be made to assess the possibility of obtaining water in the valley south of the camp. A well drilled at the camp site would probably pass through the same rocks as a well at N-0 and the action here should be deferred until after a well is drilled at $\mathrm{N}-0$. If the well at $\mathrm{N}-0$ is successful, a well up to about 400 feet deep should be drilled at $\mathrm{N}-8$.

14. N-51: 45 men; 3,000 g.p.d. required.

a. General Conditions. Situated about 500 feet above main drainage lines on the flank of Steamboat Mountain. Underlain probably by black shale. Geological structure may be complicated owing to proximity to mountains. Camp hauling water 11 miles (October 30) from Kledo River, springs at N-62 and $\mathrm{N}-49$ having dried up during summer.

b. Recommendation. Prospects for a well at the site are very poor. Inasmuch as the geologic structure is somewhat complex in the neighborhood, a geologic study of the region should be made before drilling. If such a study does not indicate more favorable ground-water prospects in the vicinity, a well up to about 400 feet deep in the camp may be tried if the camp cannot be relocated.

15. N-85: 40 men; 3,000 g.p.d. required.

a. General Conditions. Located about 20 feet above Tetsa River in a low terrace or floodplain. The camp is supplied by a dug well 10 by 10 feet in plan and 10 feet deep, dug in the gravels of the terrace a few hundred feet from the river. Water level is about 4 feet from ground surface. The well is reported to have been pumped at the rate of 350 g.p.m. for 3 hours with a drawdown of 1/2 inch. Although this report is probably somewhat exaggerated, the well undoubtedly will produce a great quantity of water. The present pump is a two-stage centrifugal. The supply line from the well has been covered and a distribution system was being put in on October 30 .

b. Recommendation. This camp is plentifully supplied with water and would take care of many times its present complement of men. A chlorination system should be installed. 
16. N-138: 40 men; about g.p.d. required.

a. General Conditions. Camp is situated about 100 feet above Toad River and about 1 mile south of the river on a bench covered by and probably underlain by glacial materials. A mountain creek, flowing several hundred g.p.m. on October 30, enters the area from the southeast and flows into the Toad River. A short mountain torrent descends to a fan southwest of the camp. Between the fans of the two creeks there is a shallow lake probably fed by ground water from the fan to the west which discharges through the fan gravels into the creek to the east. Most of the camp lies north of the highway but some buildings lie south. Ground water is probably plentiful in the gravels near the lake but is subject to pollution by the habitations south of the road, as is also the creek at points close to the camp. The camp has been hauling drinking water from Racing River about 3 miles distant and washing water was being pumped from the creek east of camp.

b. Recommendation. Water could probably be developed from a dug well at the margin of the lake about 500 feet southwest of the camp at points which would be up-gradient from the houses and not subject to contamination from them. If a dug well here is successful, this probably would be the most feasible way to develop water. If the buildings south of the road are abandoned, sources of pollution there could be sterilized and sufficient water could probably be taken at all seasons from a sump in the creek near the camp. Water from either source should be chlorinated. As a third possibility a test well could be drilled in the camp, which might find water in gravel or sand under clay at depths of less than 100 feet and if so would be the most convenient source of water.

17. N-176: About 40 men; 3,000 g.p.d. required.

a. General Conditions. Situated near Mile Post 177 about 25 feet above Muncho Lake on edge of large alluvial fan. A distribution system has been installed in the camp and during the summer water was pumped from the lake. The lines were buried to only shallow depths and the system is inoperative in winter. On October 31 the camp was hauling water from the lake and distributing it to the bunkhouses.

b. Recommendation. A well 50 feet or less deep in the north part of the camp should obtain water and would probably be preferable to an insulated line to the lake, which is an obvious possibility.

18. N-213: About 100 men; 7,000 g.p.d. required.

a. General Conditions. Situated on a terrace about 3,000 feet wide about 80 feet above the Liard River and underlain probably to depths below river level by gravel, sand and clay. Camp was hauling water from a 6-inch driven well 30 feet from the river and 40 feet deep when visited on October 31 . Drilling had begun on a well near the P.R.A. hospital about 50 feet southwest of the nurses' dormitory. The drilling rig was inadequate and had broken down when the well was 60 feet deep. The log recorded hard pan from 0-8 feet; loose rock with heavy boulders, 8-33 feet; soft silt and gravel, 33-48 feet; and hard gravel, 48-60 feet. 
b. Recommendation. Continue drilling present well to permeable deposits below river level, which probably will be struck within a total depth of 125 feet. If bedrock is struck before water is found, begin another well about 1,000 feet nearer the river.

19. N-260: About 40(?) men; 3,000 g.p.d. required.

a. General Conditions. Situated on a terrace about 150 feet above Liard River, probably underlain by alluvial sand and clay. Impermeable bedrock spurs project across river beneath terrace about 1,000 feet up river and an equal distance down river from camp. Well drilled in the last 2 months at the camp is reported to be 70 feet deep, water level 40 feet from surface, bailed at 15 g.p.m. for unspecified time. This water appears to be perched at so high a level about the nearby river as to suggest doubts as to its permanence. Coal River Relay Station is also situated here.

b. Recommendation. Make pumping test of well, watch performance carefully, and if it should fail, deepen to 300 feet if necessary unless bedrock is found at shallow depth. If further drilling is necessary avoid vicinity of bedrock spurs crossing river.

20. N-313: About 40 men; 3,000 g.p.d. required.

a. General Conditions. Situated in a bench covered with glacial deposits about 400 feet about Liard River and about one 1 mile east. Depth of glacial material cannot be inferred, nor the occurrence of ground water. Camp was abandoned on October 31 except for caretaker. Camp hauled water from Dawson Creek at about N-311 during summer and from Lake Ellen, a small shallow lake near and east of the camp, during winter.

b. Recommendation. Prospecting for water at this camp appears to be a pure gamble. The amount needed is small and careful drilling may find it at depths anywhere from 50 to 300 feet. 


\section{Water Well for Fire Protection on the Canadian Side of \\ Watson Lake Airfield \\ By Charles V. Theis \\ 24 January 1944}

1. General Characteristics of Site

a. The entire airfield appears to be located on a delta built by Windt Creek into Watson Lake.

b. The material near the surface as shown by soil tests and digging of wells consists of material grading from small gravel to medium sand.

c. Geological considerations and the results of pumping tests indicate that the gravel and sand probably extend to a depth of some tens of feet at least.

2. Pumping Test of Well

a. A dug well on the south side of the field in the Canadian section has been tested by pumping. This well is about 75 feet south of the Recreation Building and about 100 feet west of the road that runs in front of that building. It is about 550 feet from the lake and about 250 feet east of the natural channel of Windt Creek. The well is about $10 \times 10$ feet in horizontal section.

b. The data available regarding this test via telephone are confusing, but it appears that the well was pumped at the rate of 100 g.p.m. for 20 minutes and the drawdown was 1 foot. These figures have been used in the following computations:

c. The following conclusions are drawn concerning this pumping test:

(1) The water level in the well did not reach equilibrium during the short pumping test.

(2) The drawdown after a 2-hour pumping period, assumed to be the fire period, would have been significantly greater than that measured.

d. The following computations have been made on the basis of the short tests. These computations involve some assumptions as to the porosity of the material, but are believed to be correct enough for the purpose of preliminary consideration, unless the materials at greater depths should be significantly different from those near the surface.

(1) The drawdown in a dug well 10 feet in diameter would be about 1 foot for each 70 g.p.m. pumped after 2 hours pumping or about 10 feet when pumping 720 g.p.m., the capacity of the available pump. 
(2) The drawdown in a drilled well 12 inches in diameter would be about 1 foot for each 40 g.p.m. pumped after the same period or about 18 feet for 720 g.p.m.

\section{General Conclusions}

a. The pumping test indicates that the requisite fire flow could be drawn from the ground at this point, but was not long enough to give all the necessary information for design of the well system.

b. The advantage of a large diameter well is great enough to warrant recommendation that the well be dug, by clam shell or otherwise, with a diameter of about 10 feet. Such a well should extend at least 15 feet below static water level. Alternately, however, two or three properly developed drilled wells 12 inches in diameter with perforated casing could be sunk in a pit dug about to water level and pumped as a gang by suction lines from one pump. Such wells should extend 25 or 30 feet below static water level.

c. If the well should be located within 200 feet of the Lake, the performance would be improved.

d. Any well or series of wells after construction should be pumped for a period exceeding the period of use for fire and the production and drawdown carefully noted.

e. As it is understood that septic tanks discharge into the ground water at the field, the water should be chlorinated before delivery into the water mains. 


\title{
Survey of Permafrost Conditions at Koidern Repeater Station
}

\author{
By Charles V. Theis \\ 9 February 1944
}

1. A survey of permafrost conditions at Koidern Repeater Station was made by Mr. D'Appolonia and the writer on 5 February 1944. Detailed recommendations for the correction of foundation conditions at the station have been made by Mr. D'Appolonia and submitted to the District Engineer. The survey was greatly expedited by the cordial cooperation of Mr. Stoner, foreman in charge of construction for M.H.K-C-B at the site, who furnished several men for digging test pits.

2. Location and Environment. The repeater station is located on the nose of an elongated rounded hill just north of Koidern River at the crossing of the highway. It sits on the southern slope of the hill which was originally covered at the site by a sparse stand of small timber. The hill is probably composed of glacial clay with included pebbles and boulders, overlain by a veneer of peat or muskeg material. The site is underlain by permafrost from a depth of about

2 feet to a depth of at least 42 feet as reported in the log of a well at the building.

3. Settlement of Building. Spirit levels run inside the building indicate that the floor between the generators has sunk relative to the surrounding area a little more than 2 inches. The top of the north generator base is level and gives no evidence of settlement, and the west end of the south generator base is 0.1 foot lower than the east end, but there is no other evidence of settlement. The northwest corner of the living quarters and adjacent area in the kitchen, near the shower room, kitchen range, and furnace room have also settled a little over 2 inches. The floor of the equipment room is uneven, some points being lower than others as much as 1-1/2 inches, but no point being lower than the general level of the floor (more than 1/2 inch). Evidence discussed later indicates that much of the uneveness in this room is due to frost heaving rather than settlement. The concrete slab under the furnace has broken and sunk about 1 foot.

4. Test Pit No. 1 .

a. Location. The first of three test pits dug was located at the supporting post near the middle of the south side of the north generator base. This and Pit No. 2 showed that the supporting posts rest on a 2- $x$ 8-inch plank laid across 3 other $2 \times 8$ 's. No moss was placed under these posts or footings as had been reported elsewhere. It was reported by one of the workman who had placed some of the footings that the permafrost level was at the base of the posts and that space for the footings was excavated into the permafrost. This construction occurred in the last week of August 1943. 
b. A section of the test pit showed the following:

Surface of ground

1.0 foot Frozen, brown, peaty, root-bearing clay

.35 foot Thawed black clay.

Base of supporting post

0.3 foot Thawed black clay.

Base of $2 \times 8$-inch footing

0.1 foot Thawed black clay.

0.5 foot Black clay with ice lenses up to 2 inches long and $1 / 2$ inch thick. Clay was easy to dig and was perhaps in process of

1.5 feet (Auger hole) Black clay with a few pebbles and ice crystals. Not solidly frozen except perhaps in last 2 inches.

Temperature 1.4 feet below footing: $-1^{\circ} \mathrm{C}$.

c. Interpretation. The ground at this pit appeared much more thawed than that in Pit No. 2. The generator bases were apparently poured around an internal core of grouted rubble. The heat transmitted down from the room above at about $70^{\circ} \mathrm{F}$ and probably the heat generated during the setting of the concrete have apparently followed the concrete shell into the ground. The forms for the concrete, consisting of 2-inch planking, are still in place and this insulating cover has prevented the dissipation of the heat to the air in the 42-inch space under the building. There is no evidence that the generator base itself has settled, perhaps because the heat has not traveled down the rubble core, but the warmed and thawed ground at the side has permitted the settlement of the adjacent posts and the floor above. It is evident that the insulating forms should be immediately stripped in order to permit the dissipation of heat to the air instead of into the soil below.

5. Test Pit No. 2

a. Location. Test Pit No. 2 was dug adjacent to the seventh interior post from the west end of the building in the first interior line of posts from the north side of the building, approximately in the center of the building. Footing construction was the same as in Test Pit No. 1.

b. Section of Pit

Ground surface

0.8 foot Frozen, brown, peaty clay with pebbles and roots.

(Bottom of 8- $x$ 8-inch post)

.08 foot Same material as above.

(Top of footing. The base of the post has been raised about 1 inch clear of the footing by frost heaving.)

.35 foot Partially thawed silty, peaty clay extending below base of footing.

1.0 foot Frozen dark gray clay with thin ice lenses.

Temperature: $-3 / 4^{\circ} \mathrm{C}$.

.5 foot (Auger hole) Frozen clay.

Temperature at bottom of hole: $-3 / 4{ }^{\circ} \mathrm{C}$. 
c. Interpretation. This pit fortunately exposed the fact that part of the uneveness of the floor has been caused by frost heaving rather than settlement. It is evident that the building cannot be prevented from warping except by excavating each post and treating its surface so as to prevent adhesion of the frozen soil, an operation that is not considered feasible under the present circumstances. It appears also that there was some thawing of the permafrost since the footings were placed, which may perhaps have been caused by normal summer thaw after the footings were placed in late August and may have occurred when the ground was open during excavation for the footings.

\section{Test Pit No. 3}

a. Location. This pit was dug in the northwest corner of the furnace room. Its north wall was about 4 feet from the furnace slot and its south wall about 1 foot from the slot.

b. Section

\section{Natural Ground Surface}

North Wall

1.7 feet. Thawed brown peaty clay with roots and pebbles.

1.1 feet. Frozen brown peaty clay with pebbles.
South Wall

1.2 feet Thawed brown compacted clay with roots and pebbles.

1.2 feet Same material with excess water; very fluid.

- Frozen ground.

c. Interpretation. The test pit showed the same facts brought out in previous reports. The heat from the furnace traveling down through the thin concrete slab and about 18 inches of gravel backfill has melted the perma-frost containing many lenses of the ice with consequent settlement of the furnace. The pit shows that the heat has spread laterally inasmuch as the permafrost level in the near wall of the pit was much lower than in the far wall. The furnace must evidently be raised on posts and girders so as to permit free circulation of cold outside air over the surface of the ground beneath it.

7. Maintenance of Permafrost. Structures founded on permafrost in fine-grained materials must be so constructed as to change in the least possible way the thermal regimen of the soil. The factors influencing the occurrence of permafrost may be divided into (a) exposure factors, such as sunflight and free contact with moving air, and (b) variable-insulation factors, by which is meant materials that have different thermal properties in winter than they have in summer. The changes in these factors at the Koidern site are considered in the following paragraphs. 
8. Solar Heat. The site of the repeater station is on the south side of a hill in sparse and small timber. The construction of the building has shaded the site and cut off some of the solar heat and is therefore a favorable factor. However, some of the reported experiments from Siberia indicate that shading does not lower the soil temperature more than $1^{\circ} \mathrm{F}$, perhaps because the sun's heat warms only the upper few inches of the soil and is rapidly reradiated at night.

9. Exposure to Moving Air. The most important exposure factor seems to be access of moving air. The closing of the air space below the Koidern station by earthbanked skirting has undoubtedly kept the temperature of the soil above normal. The temperature taken in the air under the building on 5 February was $14^{\circ} \mathrm{F}$. while the air outside was at least $-15^{\circ} \mathrm{F}$. The rate of freezing of soil is probably roughly proportional to the square root of the product of air temperature below freezing and the time the low temperatures act. Because of the abnormally high temperatures under the building during the present winter it is almost certain that the depth of freezing will be less this winter than usual and that there will be a deeper thaw this coming summer. Obviously, the skirting of the building should be removed immediately in order to promote as deep freezing as possible.

10. Snow. Snow is an excellent insulator that acts only in winter and therefore does not affect the entrance of heat into the soil during the summer, and inhibits the escape of heat from the soil during the winter. The effect is to raise the temperature and thus inhibit the formation of permafrost in the areas where the average air temperature is only a little below freezing. The construction of the Koidern building has prevented the accumulation of the usual snow blanket at the site. Presumably therefore the permafrost level will tend to rise under the building, and the already frozen ground will become more rigid if the winter temperatures are allowed access to the ground. Drifting of snow under the building should be prevented.

11. Fine-Grained Wet Soil. Ice conducts heat almost 4 times as readily as water. No data are available as to the thermal conductivity of fine-grained soils in the frozen and unfrozen condition but there can be little doubt that the present of moist soilds near the surface promotes the formation of permafrost as is indicated by the fact that permafrost is commonly present under muskegs. At Koidern the underlying material is a saturated clay. The surficial material has not been greatly distributed and apparently no particular precautions to control this factor are necessary except to smooth out the surface to prevent the accumulation of water and the development of an irregular and hummocky surface of the permafrost.

12. Conclusions. In order to preserve the permafrost conditions at the Koidern stations, the following steps should be taken:

a. Remove skirting immediately to allow free access of cold air.

b. Remove form work around generator bases to allow the dissipation of heat carried from the room downward.

c. Place furnace on raised floor to allow free movement of cold air over the surface of the ground beneath the furnace floor.

d. Prevent accumulation of snow below the building. 


\title{
Pumping Test on Well at N-0
}

\author{
By Charles V. Theis
}

10 February 1944

1. The data submitted by M.H. K.C.B. on the pumping test at N-0 on 14 January indicate an anomalous rate of drawdown in the well. The water level fell at a diminishing rate in a normal way for 6 hours of pumping at 8 g.p.m. to a position 22 feet below static level. During the next 4 hours it fell at uniform rate of 2-1/2 feet per hour and was still falling at the end of the test, which is an unusual condition inasmuch as all water-bearing beds are indicated by the log to lie below the lowest pumping level.

2. The data may be significantly inaccurate, in which case the following deductions will be in error.

3. Assuming the data are accurate, all the water-bearing beds occur above a depth of 70 feet, and the ultimate capacity of the well is a trifle less than 8 g.p.m. pumping from a depth of 70 feet or with a drawdown of 22 feet. No advantage would be gained by lowering the water farther.

4. The water is perched several hundred feet above the main water table. Not enough is known about the circulation of ground water in the area to make a certain prediction as to the permanence of this well, but perched water is apt to fail in dry weather.

\section{Recommendations}

a. Repeat pumping test on this well, making sure all measurements are accurate, and continuing it until the drawdown is stabilized.

b. In case adequate water is desired for the full complement of 350 men at the camp, drill two additional wells at about 500 -foot centers about 100 feet deep. 


\title{
Grande Prairie Air Base Water Supply
}

\author{
By Charles V. Theis \\ 16 February 1944
}

1. This memorandum is largely comment on a memorandum on the same subject by Mr. T.J. Netland dated 9 February 1944.

2. From various sources on file in the Engineering Branch, it appears that No. 1 Well was drilled 270 feet but is now backfilled to about 240 feet. Well No. 2 is 210 feet deep and Well No. 3 is 216 feet deep. All wells apparently draw water from sandstones in the Belly River formation. All wells apparently produce water high in sodium bicarbonate, although water from Wells 2 and 3 is apparently slightly harder than that from Well No. 1.

3. The reported 60 -foot drop in static water level from 40 to 100 feet below the surface in Well No. 2 after operation during only 1 year is surprising and alarming. If true, the aquifer is presumably a lens and is liable to exhaustion in a few years. The measurements by Mr. Netland confirm in a rough way the reported present static level and a report by Leonard Banuach to J.H. Gehbauer dated 10 July 1943 (copy in Engineering Branch) confirms the original water level. Hence Mr. Netland's recommendation to deepen Wells 2 and 3 to a second aquifer at about 240 feet encountered in Well No. 1 is concurred in.

4. Mr. Netland reports that Well No. 1 is crooked as well as out of plumb, that the casing has broken at the bend in the hole, and that the well is pumping muddy water as a consequence. Inasmuch as a third well is required to furnish the needs of the camp as at present constituted, Mr. Netland's recommendation to drill another well is also concurred in.

5. According to report, the water level in the airport wells was originally about 50 feet below the surface and that at the town, about 5 miles east, was about 140 feet deep, although the town is about 50 feet lower than the airport. Such a discordance of water levels in a short distance suggests, independently of the drop in water levels discussed in 3 above, that the water occurs in lenticular beds that will continue to yield water only with progressively more difficulty. To form an opinion or real validity on this point would require a ground-water study of the area involving the acquisition of data on logs of wells and history of water levels and pumping rates of older wells in the district. 


\title{
Study of Water Supply for the Alaskan Wing Stations
}

\author{
By Charles V. Theis
}

29 February 1944

\section{General}

a. There is included herewith Table 1 (not found in archives) giving the available pertinent data on water supply wells for airports of the Alaskan Wing. Short descriptions of the wells at the airports are given in the following.

b. For the purposes of the report to be rendered to the Air Forces, additional data on the distribution and fire systems should probably be tabulated.

c. The following information should be obtained from the District Engineers:

Dawson Creek. Name plate data on all pumps and power units in the water systems at all airports; complete description of the wells at Prince George, giving depth, diameter, type of casing and log; pumping test on wells at Prince George, with accurate measurement of static water level (below top of casing or ground level), pumping rate, drawdown, and pumping level; similar pumping tests on the wells at Grande Prairie.

Whitehorse. Name plate data on all pumps and power units in water systems at Watson Lake and Whitehorse air bases; pumping test on Well No. 2 at Watson Lake.

Fairbanks. Name plate data on all pumps and power units in the water systems at Northway, Tanacross, and Big Delta Airfields; complete log on Northway Well No. 2; pumping tests on Northway Well No. 2, Tanacross Wells 1 and 2, and Big Delta Well No. 1, with accurate measurements of static level, pumping rate, drawdown, and pumping level.

d. Samples of water should be collected and complete analyses determined by a single agency. The available analyses are so divergent in content that they cannot be tabulated.

\section{Grande Prairie}

a. Wells at Grande Prairie Airport apparently penetrate about 150 feet of glacial clay and sand and then enter bedrock, which consists of shaly sandstone, sandstone, and shale of the Wapiti or Belly River formation of the Upper Cretaceous series. These beds, although among the better waterproducing beds of Alberta, appear to be thin and fine grained and can be expected to yield only about 10 or 20 gallons of water a minute. 
b. Measurements made in February 1944 indicate that the static water level in Well No. 2 has probably fallen about 60 feet below its position when drilled in 1942. No measurements on other wells have been possible owing to the type of construction. All aquifers in the Cretaceous rocks in Alberta must be assumed liable to exhaustion until proved otherwise because they are fine grained, probably lenticular, and the opportunities for recharge owing to a tight soil cover are limited. It is probable that with continued use of the airport it may be necessary to drill additional wells.

c. In order to be prepared for any diminution of the existing water supply, a record of water levels in the existing wells should be maintained. Once a month or perhaps oftener, at a time of day when the demand for water is least, each of the wells should be disconnected from service for a fixed time, at least $1 / 2$ hour, and after this recovery the depth to water should be carefully measured, preferably with a steel tape. If such a record shows continued lowering of water levels, plans can be made for supplementing the supply.

d. No logs of the wells have been preserved.

3. Prince George

The wells at Prince George derive their water by infiltration from Fraser River and therefore should be of a permanent nature. The water has about the same chemical character as that of the river. The water is hard and contains a large amount of iron. Particular attention must therefore be given to the operation of the treatment plant.

\section{Ft. Nelson}

a. The wells at Ft. Nelson Airport are drilled in a pre-glacial channel of the Ft. Nelson River drainage backfilled with clay, gravel and sand deposited by or in connection with glaciers. The base of these unconsolidated deposits is at a depth of 717 feet or perhaps 725 feet in No. 1 well or at an elevation only about 450 feet above sea level. The water is obtained in a gravel and sand bed encountered in Well No. 1 from 672 feet to 717 feet and in Well No. 2 at about the same depth. These wells are entirely different in character from the well at N-0 Relay Station and other wells in the vicinity of Ft. Nelson, which penetrate bedrock. The water in the airport wells has a light yellow color and contains a large amount of dissolved methane, both probably produced by peaty deposits in the glacial sediments.

b. Well No. 2 will in all probability continue to produce water enough to satisfy the demands of the airfield indefinitely. In case of breakdown, Well No. 1 can be used. This well produces a murky water, probably because of the erosion of clay opposite the higher perforations in the casing and the water would require sedimentation treatment if used for a considerable time.

c. Log of Well No. 1, north of water tank: 


\begin{tabular}{|c|c|c|c|}
\hline From & $\begin{array}{c}\text { To } \\
\text { (Feet) }\end{array}$ & Thickness & \\
\hline 0 & 150 & 150 & Not recorded \\
\hline 150 & 210 & 60 & Blue Clay \\
\hline 210 & 213 & 3 & Gravel \\
\hline 213 & 224 & 11 & Blue Clay \\
\hline 224 & 228 & 4 & Gravel \\
\hline 228 & 257 & 29 & Clay with Gravel Bands \\
\hline 257 & 265 & 8 & Sandstone \\
\hline 265 & 270 & 5 & Boulders and Gravel \\
\hline 270 & 290 & 20 & Sandstone \\
\hline 290 & 292 & 2 & Boulders \\
\hline 292 & 300 & 8 & Clay and Gravel \\
\hline 300 & 320 & 20 & Clay \\
\hline 320 & 330 & 10 & Clay and Coarse Gravel \\
\hline 330 & 340 & 10 & Clay and Sandy Gravel \\
\hline 340 & 350 & 10 & Blue Clay \\
\hline 350 & 400 & 50 & Clay \\
\hline 400 & 410 & 10 & Clay and Coarse Gravel \\
\hline 410 & 430 & 20 & Clay \\
\hline 430 & 450 & 20 & Gravel \\
\hline 450 & 500 & 50 & Fine Gravel--Sand \\
\hline 500 & 530 & 30 & Clay \\
\hline 530 & 540 & 10 & Clay and Gravel \\
\hline 540 & 672 & 132 & Clay \\
\hline 672 & 717 & 45 & Coarse Gravel \\
\hline 717 & 725 & 8 & Hard Band \\
\hline 725 & 910 & 185 & Dark Shale \\
\hline 910 & 1,160 & 250 & Sandy Shale \\
\hline 1,160 & 1,250 & 90 & Dark Shale \\
\hline 1,250 & 1,260 & 10 & Hard Band \\
\hline 1,260 & 1,450 & 190 & Black Shale \\
\hline
\end{tabular}


d. Log of Well No. 2, east of water tank:

\begin{tabular}{rcrl} 
From & $\begin{array}{c}\text { To } \\
\text { (Feet) }\end{array}$ & Thickness & \\
\cline { 2 - 3 } 0 & 150 & 150 & Not recorded \\
150 & 187 & 37 & Blue Clay \\
187 & 217 & 30 & Clay and Sand \\
217 & 237 & 20 & Gravel and Clay \\
237 & 250 & 13 & Calsite Crystalline Gravel \\
& & & and Boulders \\
250 & 440 & 190 & Coarse Sand and Gravel \\
440 & 480 & 40 & Gravel \\
480 & 522 & 42 & Soft Blue Plastic Clay \\
522 & 674 & 152 & Soft Blue Plastic Clay \\
674 & 689 & 15 & Coarse Gravel \\
689 & 694 & 5 & Coarse Gravel \\
694 & 697.5 & 3.5 & Coarse Gravel \\
697.5 & 706 & 8.5 & Coarse Gravel
\end{tabular}

Casing record--10-3/4" O.D. to 150', 7" O.D. to 680'. Not perforated.

5. Watson Lake

a. The wells at Watson Lake are dug in an alluvial fan built into the lake. The water supply can be increased, if desired, many times by deepening the wells or adding new ones.

6. Northway

a. The wells at Northway Airport are drilled through alluvial deposits of sand, gravel, and silt to cleaner gravels at their bottoms. Permafrost is reported to extend to a depth of 55 feet in Well No. 1 and to 90 feet in Well No.2. The available quantity of water is probably large and wells will not fail because of lack of water. Two difficulties in water supply may arise. First the wells are left idle for some time, the water in them may freeze in the permafrost zone and, therefore, both should be pumped daily. Second, it is possible that the fine silts prevalent in the gravels may break into the wells or clog the screens. If this should happen, the wells should be redeveloped by surging or heavy pumping interrupted by cutting off the pump so that the water can run rapidly back in to the aquifer, and such other procedure as will loosen the silt and pump it away from the immediate vicinity of the well. 
b.Log of Well No. 1 (drilled by Engineer Troops), north of dispensary:

\begin{tabular}{rrrl} 
From & $\begin{array}{c}\text { To } \\
\text { (Feet) }\end{array}$ & Thickness & \\
\cline { 1 - 2 } 0 & 5 & 5 & Silt \\
5 & 60 & 55 & Frozen silt \\
60 & 80 & 20 & Sand \\
80 & 95 & 15 & Silt \\
95 & 106 & 11 & Silt and sand \\
106 & 208 & 102 & Silt and gravel
\end{tabular}

c. Log of Well No., 2, north of hangar:

\begin{tabular}{|c|c|c|c|}
\hline From & $\begin{array}{c}\text { To } \\
\text { (Feet) }\end{array}$ & Thickness & \\
\hline 0 & 25 & 25 & Frozen silt and ice \\
\hline 25 & 40 & 15 & Frozen sand and ice \\
\hline 40 & 77 & 37 & $\begin{array}{l}\text { Frozen silt and sand } \\
\text { and ice }\end{array}$ \\
\hline 77 & 90 & 13 & $\begin{array}{l}\text { Frozen silt; bottom of } \\
\text { permafrost. Water rose to } \\
15 \text { feet below surface. }\end{array}$ \\
\hline 90 & 120 & 30 & Sand and some gravel \\
\hline 120 & 125 & 5 & Soft blue clay \\
\hline 125 & 140 & 15 & Peaty silt \\
\hline 140 & 145 & 5 & Sand \\
\hline 145 & 167 & 22 & $\begin{array}{l}\text { Sand and thin beds of } \\
\text { gravel. Well pumped at } \\
\text { about } 12 \text { gpm, but water } \\
\text { carried too much sand }\end{array}$ \\
\hline 167 & 223 & 56 & Fine sand and gravel \\
\hline 223 & 236 & 10 & $\begin{array}{l}\text { Not known; probably fine } \\
\text { sand and gravel }\end{array}$ \\
\hline 236 & 246 & 10 & Coarse gravel; water \\
\hline
\end{tabular}




\section{Tanacross}

a. These wells are drilled into the alluvial sand and gravel near the Tanana River. The water table is shallow and no permafrost is present. The existing wells will furnish considerably larger quantities of water than is necessary at present if equipped with larger pumps, although if this is done it may be necessary to redevelop the wells to remove silt. The water supply can be indefinitely increased by drilling additional wells.

b.Log of Well No. 1, east of Barracks Building 104:

\begin{tabular}{|c|c|c|c|}
\hline From & $\begin{array}{c}\text { To } \\
\text { (Feet) }\end{array}$ & Thickness & \\
\hline 0 & 6 & 6 & Gravel and silt \\
\hline 6 & 9 & 3 & Medium gravel and sand \\
\hline 9 & 15 & 6 & Coarse gravel and sand \\
\hline 15 & 18 & 3 & Very fine gravel and sand \\
\hline 18 & 21 & 3 & Sand with medium gravel \\
\hline 21 & 25 & 4 & Sand with coarse gravel \\
\hline 25 & 36 & 11 & Medium gravel and sand \\
\hline 36 & 38 & 2 & Coarse gravel and sand \\
\hline 38 & 41 & 3 & Medium gravel and sand \\
\hline \multirow[t]{2}{*}{41} & 43.7 & 2.7 & Coarse gravel and sand \\
\hline & 45 & & TOTAL DEPTH \\
\hline
\end{tabular}

c. Log of Well No. 2, northwest of dispensary:

To

From $\quad$ Feet

0

$5 \quad 9$

920

$20 \quad 26$

$26 \quad 42$
Thickness

$5 \quad$ Gravel and sand

$4 \quad$ Fine gravel and sand

11 Medium gravel and sand

6 Sand with a little gravel

16 Coarse gravel and sand 
8. Big Delta

a. These wells are in alluvial gravel, sand and silt near Big Delta River. No permafrost is present. The water table is deep but additional quantities can be obtained from these wells by larger pumps and the supply further increased if necessary by deepening these or drilling other wells.

b. Log of Well No. 1, about 400 feet east of hangar:

To

From (Feet) Thickness

\begin{tabular}{|c|c|c|}
\hline 4 & 4 & Soil \\
\hline 10 & 6 & $\begin{array}{l}\text { Gray coarse sand and fine } \\
\text { gravel }\end{array}$ \\
\hline 40 & 30 & Gray coarse sand and gravel \\
\hline 50 & 10 & Coarse sand and gravel \\
\hline 60 & 10 & $\begin{array}{l}\text { Brown silty and micaceous } \\
\text { sand }\end{array}$ \\
\hline 70 & 10 & Fine to medium sand \\
\hline 80 & 10 & $\begin{array}{l}\text { Silty, clayey, fine to medium } \\
\text { sand }\end{array}$ \\
\hline 90 & 10 & Brown sandy silt and clay \\
\hline 100 & 10 & $\begin{array}{l}\text { Brown silty medium to coarse } \\
\text { sand }\end{array}$ \\
\hline 110 & 10 & Brown micaceous silt and sand \\
\hline 130 & 20 & $\begin{array}{l}\text { Brown medium cemented sand, } \\
\text { some pebbles }\end{array}$ \\
\hline 140 & 10 & Brown silty micaceous clay \\
\hline 150 & 10 & $\begin{array}{l}\text { Brown and gray coarse sand } \\
\text { and gravel }\end{array}$ \\
\hline 170 & 20 & Brown coarse sand and gravel \\
\hline 180 & 10 & As above, some pebbles \\
\hline 190 & 10 & $\begin{array}{l}\text { Coarse sand and gravel; water } \\
\text { at } 184 \mathrm{ft}\end{array}$ \\
\hline 199 & & Bottom of hole \\
\hline
\end{tabular}

c. No log available for Well No. 2, located near Barracks 313 . 


\title{
Foundation Movement at Northway Repeater Station
}

\author{
By Charles V. Theis
}

9 March 1944

1. An inspection of foundation conditions at Northway Repeater Station was made by Mr. Beaudry of the District Office and the writer on March 5,1944. Levels were run inside the building, an inspection made inside the building and underneath it and three footings were excavated at critical points.

2. General condition of building. The most obvious deformation observed in the building was a relative rise of about 3 inches in the center of the north side of the building with respect to the center of the building. Relative elevations on the floor of the building are shown in the accompanying sketch. The general aspect is of a floor that is in general about 2 inches lower in the center, near the equipment, than at either end. It was reported also that the door opening into the heater room had been thrown out of line so that it had to be planed off at the bottom in November and again in January. This and door frames now appear square and undeformed. The building was first occupied in August, equipment was moved in in September and the first deformation became evident with winter in November. It increased as temperatures fell. In the heater room a prominent crack in the floor slab extends from the south (interior) wall to the furnace and a few fine cracks elsewhere. The floor slab has apparently settled a maximum of 3/4 inch below the pour line as shown on part of the form left against the south wall, but also about the same distance against the north wall. These conditions may be entirely due to settlement over an imperfect fill and would be ordinarily so ascribed were it not for the more extensive and move evident settling due to melting of permafrost in Koidern Repeater Station.

3. General condition of foundations. The interior posts are carried to pads whose bases are about 1 foot below the ground level and rest on frozen silt. The holes for the bases have not been backfilled and the frozen ground is exposed. Dry black medium-grained sand is backfilled between the generator bases and underlies the pads between the bases. The load is unevenly distributed over the posts. The girder cleared one post by 1-1/2 inches and another by $1 / 2$ inch so that these posts were entirely loose. No corresponding sags in the floor were noted at these points. The surface of the ground under the building is dry and powdery to a depth of about 1 inch. The temperature at the surface of the ground under the building at the time of inspection was $30^{\circ} \mathrm{F}$ about 10 feet from the ventilator opening and $38^{\circ} \mathrm{F}$ about 40 feet from the opening. The outside air temperature at the time was $17^{\circ} \mathrm{F}$. The temperature at the base of the pad in the first location was $28^{\circ} \mathrm{F}$ and at the second, $31^{\circ} \mathrm{F}$. The temperature in the soil about 4 inches below ground level at the west post of the two opposite the furnace room was $44^{\circ} \mathrm{F}$ and at the eastern of the two, at a depth of 
8 inches, it was $36^{\circ} \mathrm{F}$. Surface temperatures are therefore above freezing at the ground surface throughout the building except near the ventilator and are particularly high near the furnace room. However, there is no sagging of the floor level near the furnace room.

4. Footings. Three footings were excavated in all, one on the south side of the building and two under the high point on the north side. The locations of the supports excavated are shown in the accompanying diagram together with the conditions found. The post on the south side extended about 1.3 feet below ground level and originally rested on a pad of two 3-inch planks. The post was found to be raised about 1/4 inch clear of the underlying pad. The pad rested on frozen volcanic ash which is prevalent near the ground surface throughout the Northway area. The posts excavated on the north side extended barely to ground level, the base of the pads being about 6 inches below ground level. Both pads were embedded in frozen silt and an excavation made to a depth of about 1 foot below the base of the pad in the westermost of the posts excavated revealed the same material. Both posts rested on their pads but the most easterly of the pads was raised clear of the ground beneath it about 3 inches by frost heaves of the soil near the surface firmly adfrozen to the pad. The pad under the western of the two posts seemed at first sight to be resting securely on the ground, but when frozen soil and ice extending about an inch under the pad was chipped out it was shown also to been raised by frost heaving clear of the ground at its base about 2 inches.

5. Conclusions.

a. The present warping of the floor is probably due almost, if not quite entirely, to frost heave as shown by the visual evidence of heave under the high points of the building and by the fact that the deformation first became noticeable with the advent of winter and increased with dropping temperatures.

b. The floor was probably somewhat out of level after its first loading. This is suggested by the fact that the east and west ends of the building are higher than the center except where the footings are demonstrably frost heaved and that this has no apparent relation to exposure to the sun or to nearness to warm spots such as the furnace room.

c. The cracking of the slab in the furnace room is probably due to melting of frozen ground by the warmth of the furnace, but if so has not progressed far enough to demonstrate this.

d. Although the present disturbance is at least largely due to frost heave, there is a distinct possibility that the central and south supports will settle during the summer. The ground temperatures under the building are now above freezing with the consequence that the ground will go into the summer abnormally warm.

6. Recommendations.

a. Reset the footing pads on the north side to a minimum depth of 18 inches to eliminate cumulative frost heave. Paint posts with asphalt paint and wrap them with a collar or muff of moss 3 inches thick. Backfill with sand. 
b. Backfill around interior posts with moss or peat to minimize melting of frozen material below. This should be done before thaw begins.

c. After ground has thawed level up building by shimming over posts.

d. Inspect furnace room every 2 weeks. If the slab shows clear evidence of settlement, slab and furnace should be raised off the ground on posts and girders to give a 2 foot minimum clear air space between ground and girders. The space should not be skirted. The posts should be set at least 2 feet into permanently frozen ground. If solid rock is found at less depth, posts may be set on that.

e. After building has been leveled, inspect about once a month. If further settlement occurs on south side or interior of building skirting should be removed around building and floor insulated so as to permit winter temperatures access to the ground. 


\title{
Installation of Underground Gasoline Storage Tanks
}

\author{
By C. V. Theis
}

\section{March 1944}

1. Reference is made to letter of Lt. Col. Lockridge, 9 March 1944, subject: "Installation of Underground Gasoline Storage Tanks."

2. If safety or other engineering considerations make it advisable to use underground storage tanks of light metal, the destructive action of ground swelling during freezing can be minimized and probably prevented by (a) setting the tanks in porous, drainable soils and/or (b) insulating the ground to prevent or minimize freezing.

3. As suggested by Lt. Col. Lockridge, the tanks should preferably be set in naturally occurring high porous ground. If such a site is available in a convenient location, tanks set in it would presumably be safe from frost-swelling.

4. If tanks must be set in tight, poorly drained ground, such as characterizes many of the airports, the following remedial steps to provide less active ground around the tanks may be taken.

a. The tops of the tanks should be set below ground level, probably a minimum of 2 feet.

b. The hole should be excavated to a larger size than the tanks and back-filled with porous sand or gravel so that this backfill extends several feet beyond the tanks in all directions.

c. If possible, the backfill should be provided with drains.

d. Impermeable material should be graded up over the tank site to provide surface drainage away from the site.

5. In such poor locations, steps should also be taken to insulate the surface to impede the entrance of frost into the ground.

a. The best solution would be to provide a low shed or box over the site extending probably a minimum of 5 feet in all directions beyond the tanks, floored and roofed to prevent the access of water, and filled with at least 1 foot of dry moss or best commercial insulation.

b. As a minimum safeguard, the snow cover should be preserved by fencing the site to prevent trampling of the snow and so destroying its insulating value. 


\title{
Foundation Conditions at Northway Hangar
}

\author{
By Charles V. Theis
}

17 March 1944

1. Introduction. The foundation conditions at Northway hangar were reviewed by Mr. E. E. Beaudry and the writer on March 5, 1944. Inspection was made of test pits at the site of the water tank, temperatures taken in test holes in the hangar floor, and the history and prospects of settlement discussed with Captain Nelson, Mr. McConnell and others of the area office.

2. Geological Conditions. The airport is located on alluvial materials dropped by the Nabesna and Chisana Rivers. The alluvium extends to a depth of over 246 feet as shown by the log of the well at the hangar. Permafrost extended to a depth of 90 feet in this well.

3. Five test pits have been excavated to a depth of 6 to 8 feet at the site of the water tank some 400 feet east of the hangar and a little north of the north line of the hangar. The pits are within a radius of about 25 feet and are consequently much alike. The undisturbed samples have been taken from each of these pits by $\mathrm{Mr}$. McGuire of M.H.K.C.B. and are being taken in a frozen condition to Edmonton for determination of water content and bearing pressure when thawed. The section exposed in the southeastern one of the

5 test holes is as follows:

From - To - Thickness

Gravel up to size of hen egg of various dark rocks embedded in silt

$\begin{array}{rrrr}.5 & .8 & .3 & \\ .8 & 1.0 & .2 & \\ 1.0 & 3.5 & 2.5 & \end{array}$

Fine brown silt.

Dark silty sand with gravel.

Silt and fine sand; some laminated horizontally, some coarser parts cross-bedded. Included lenses of black sand like underlying material.

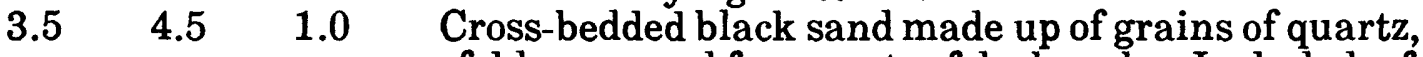
feldspars, and fragments of dark rocks. Included a few pebbles on cross-bedding planes.

4.5 $\quad 4.7 \quad 0.2 \quad$ Gravel layer; various fine-grained dark or pink crystalline rocks.

$\begin{array}{lll}4.7 & 7.0 & 1.3 \quad \text { Medium-grained black sand with a few pebbles like that at }\end{array}$ 3.5-4.5 feet. 
4. A section in the southwestern test pit was as follows:

From - To - Thickness
$\begin{array}{lll}0 & 0.3 & 0.3 \\ 0.3 & 2.0 & 1.7\end{array}$
Brown, peaty, material.
$\begin{array}{llll}0.3 & 2.0 & 1.7 \quad \text { Silt and fine sand in small wavy lenses or horizontal }\end{array}$
$2.0 \quad 3.0 \quad 1.0 \quad$ Cross-bedded, black, medium-grained sand, with some silt
$\begin{array}{lll}3.0 & 3.5 & .5\end{array}$
$3.5 \quad 7.0 \quad 3.5$ laminae.

5. Foundation at Hangar. The site of the hangar was used for a borrow pit during the construction of the first runways by the C.A.A. in the summer of 1942. Permafrost was encountered at the site. In 1943 the pit was backfilled with medium-grained black sand, much like that seen in the pits described above, to an average depth of 4 or 5 feet and the building placed upon it. The floor slab is placed directly on the backfill, and is independent of the rest of the structure The footings supporting the walls and roof trusses are carried to a minimum of 5 feet 10 inches below grade and are therefore below the backfill in most places.

6. General Conditions of Heat Transmission Under Heated Building. If a floor slab warmed to room temperature is placed directly on the ground in a cold region, the heat of the slab will be conducted through the ground to the exterior of the building and the temperature of the ground under the building will rise. In homogeneous ground-water climatic conditions, such as those at Northway, temperatures under the building will eventually rise above freezing to a depth at least equal to the width of the building. The rapidity of thawing of frozen ground under the building will depend upon the conductivity of the underlying materials and the water content of the soil. In the materials under the hangar, it is probable that thawing will proceed in the initial stages at a rate approximating 1 inch a week and will decrease as the depth of thaw increases.

7. Present Recession of Permafrost Under Hangar. Seven holes have been left in the floor of the hangar through which the depth of frozen ground has been measured periodically by probing with a driven rod. The location of these holes is shown in the accompanying sketch and the following table give the data assembled: 
Depth to frozen ground (in inches) and temperatures $\left({ }^{\circ} \mathrm{F}\right)$ under hangar floor at Northway

\begin{tabular}{lccccccc}
\multicolumn{1}{c}{ Date } & $\begin{array}{c}\text { Hole } \\
\# 1\end{array}$ & $\begin{array}{c}\text { Hole } \\
\# 2\end{array}$ & $\begin{array}{c}\text { Hole } \\
\# 3\end{array}$ & $\begin{array}{c}\text { Hole } \\
\# 4\end{array}$ & $\begin{array}{c}\text { Hole } \\
\# 5\end{array}$ & $\begin{array}{c}\text { Hole } \\
\# 6\end{array}$ & $\begin{array}{c}\text { Hole } \\
\# 7\end{array}$ \\
& 66 & 172 & 84 & 66 & 132 & 63 & 112 \\
Sept. 30, 1943 & 100 & 172 & 88 & 67 & 138 & 46 & 112 \\
Dec. 7, 1943 & 102 & 171 & 91 & 66 & 140 & 38 & 116 \\
Jan. 15, 1944 & 108 & 172 & 93 & 69 & 138 & 42 & 124 \\
Feb. 2, 1944 & 111 & 173 & 97 & 69 & 141 & 38 & 50 \\
Feb. 16, 1944 & 115 & 173 & 99 & 71 & 142 & 46 & 54 \\
March 2, 1944 & - & - & - & - & - & - & 136 \\
March 5, 1944 & & & & & & & \\
Temp. of Floor Slab & 570 & 540 & 410 & 500 & - & 390 & 400 \\
March 5, 1944 & & & & & & & \\
$\begin{array}{l}\text { Temp. in Hole } \\
\text { March 5, 1944 }\end{array}$ & 440 & 510 & 440 & 500 & - & 390 & 340 \\
$\begin{array}{l}\text { Depth at which } \\
\text { temp. was measured }\end{array}$ & 45 & 26 & 1 & 24 & - & - & 48
\end{tabular}

8. The readings indicate that two layers of frozen ground are involved and that the depth to the underlying main layer is variable. In hole No. 7 the two shallow readings were shown by experiment on March 5 to represent a shallow thin layer through which the rod could be driven with difficulty to the main layer at greater depth. The unevenness of the surface and the presence of the upper layer probably originated during refreezing of the ground during the winter of 194243, after excavation during the preceding summer. The present depth to frozen ground increases from northeast to southwest. The recession of the frost level noted since occupancy of the building in December appears erratic but all holes except No. 6 show some recession. In hole No. 3 , in the center of the building and which shows a consistent record, the recession was 11 inches in the approximately 8 weeks of occupancy.

9. Conclusions.

a. There will be extensive thawing of material under the hangar with continued occupancy, indicated both by the theory of heat flow and by the record of the last 2 months of the recession of permafrost.

b. The stability of the building will depend entirely upon the characteristics of the underlying soil to a considerable depth with regard to volume change during thawing and with regard to bearing strength in the thawed condition. 
c. the material exposed to a depth of 8 feet some 400 feet from the hangar appears to be coarse enough to maintain stability on thawing. Tests on samples now presumable on the way to Edmonton should demonstrate the character of this material definitely. However, it is possible and even somewhat probable that finer materials with possibly a very high water content when thawed may be present within the limits of thaw.

d. The fact that the frost level has receded under the hangar in the neighborhood of 1 foot without evidence of settlement is on the whole a favorable indication as it shows that at least at this depth the material has considerable bearing strength in the thawed condition. However, as expressed in $c$ above, finer and less stable materials may be present without the depth of interest.

\section{Recommendations.}

a. Dig test pit to a depth of 8 to 10 feet at hangar located about 15 feet east of the building and in line with the south interior set of footings. Arrangements were made with Captain Nelson and M.H.K.C.B. personnel to have this pit dug and samples taken to Edmonton for testing along with the ones already taken from test pits at the water tank. According to plan, it should not be on the way to Edmonton.

b. Located additional test holes in boiler rooms at hangar to measure the depth of permafrost periodically as is being done in the holes in the hangar floor. One hole is to be located as close to the furnace as possible, one as close to the interior column near the furnace as possible, and one near the drainage and sewer sump in the corner of the furnace room. This procedure was also discussed with and agreed to by Captain Nelson. These holes should be placed and initial readings of permafrost level taken immediately, before the furnace has been in operation long.

c. Dig 3 test shafts at least 25 and preferably 30 feet deep near the hangar, one just west of and one just east of the north interior lines of footings and one near the center of the north side of the building. These shafts should be inspected by a competent engineer during the digging and samples should be cut in the frozen condition from all beds which are of such nature as to suggest that they would change volumetrically upon thawing or would have little loading strength when thawed. If no beds are suspected of such characteristics, a volumetric sample should be taken of the finest grained bed in each interval of 5 feet. The frozen samples should be tested in a soil testing machine for volumetric change or thawing and for bearing strength when thawed. They must be transported in a frozen condition or tested on the job. 
d. Maintain a close inspection of the walls and floor slab of the building for cracking or other signs of failure of the slab or foundations. Especially close inspection should be given to the furnace room and nearby supports of the roof trusses as thawing will almost certainly proceed most rapidly here and signs of failure here will give advance notice of possible general failure.

e. If test shaft samples show the presence of material which will have little strength when thawed, or if signs of excessive settlement become visible, some means must be taken to cool the soil under the floor slab and leantos. The most feasible way to do this will have to be determined by further study and discussion. Tentatively it appears most feasible to put in a false floor and use an artificial cooling system. Such a system would probably involve placing reinforcing steel at about 6-inch centers over the present floor to give good head conduction to a system of cooling pipes laid across the steel at about 10- or 15-foot centers. This cooling system would be covered by about 1 foot of cinder or slag concrete or any better insulator that could be used, and the surface slab placed on this. Temperatures in the cooling solution would have to be maintained several degrees below freezing. 


\title{
Foundation Conditions at the Power House (Bldg. No. 116) at Northway Airport
}

\author{
By Charles V. Theis
}

18 March 1944

1. Consideration was given to foundation conditions under the power house at Northway Airport in the course of a general study made at the airport March 5 and 6,1944. The material underlying the power house to a depth of about 3.5 feet is largely silt and from that depth to 7.0 feet, medium-grained black sand. The material is of alluvial origin and may be expected to vary in character both laterally and vertically in a rapid manner. The material exposed in test pits at the site of the water tank just west of the power house is described at more length in a memorandum concerning the foundations at the Northway hangar submitted on 17 March 1944.

2. According to Mr. R.H. Van Hoose of M.H.K.C.B. district office at Fairbanks, the bases of the Diesel engines consist of blocks of concrete 7.5 feet thick set upon mats of cement asbestos averaging 9 inches thick, which in turn rest upon 1.5 feet of gravel backfill. Grids of 1/2-inch reinforcing steel at 6 -inch centers in both directions are set in the tops and bottoms of the mats. The floor slab of the building rests directly upon the ground surface. The exhaust of the engines is carried overhead to exhaust above ground surface in the Northway installation rather than through the engine base as in the standard installation.

3. The power house will almost certainly be maintained at ordinary room temperature or higher. The heat of the slab will pass by circuitous paths through the ground to the surface beyond the building. The ground will warm and the permafrost will recede. The recession of the permafrost under the slab may be expected to be of the order of a foot or two in the first month the building is warmed, but will be at a decreasing rate with increasing time and will probably extend to a depth of 15 or 20 feet in 5 years. These estimates are subject to revision when the water content of samples from the test pits at the site of the water tower is determined. Recession of the permafrost under the engine base will be slower. After a period during which the concrete base is warming up, which may be expected to last about a month, the permafrost may be expected to recede at the rate of about an inch per week for a time.

4. The stability of the engine bases as well as the remainder of the building depends, therefore, upon the characteristics of the foundation material after thawing down to the depth that will eventually be thawed. The material shown in the nearby test pits appears to be such that it will have good loading strength when thawed. Tests being run on samples from the pits will give conclusive evidence as to the characteristics of this rather shallow material. However, the thawing will in all probability exceed this depth and if there are typical finegrained permafrost materials with a very high water content within the depth of thaw, they will endanger the building and engine foundations. 
5. Recommendations.

a. Open at least one hole in the slab through which to measure twice a month the recession of the permafrost by probing as is being done in the hangar floor. This hole should be close to the north end of No. 2 engine base near the center of the building.

b. Take elevations once a month on the corners of the engine bases. These should be referenced to a stable bench mark, the best location for which is probably in the south foundation wall over the entrance of the air intake pipes. An evidence of unusual settlement should be followed by immediate corrective action.

c. Dig test shaft north of building at least 25 feet deep, taking volumetric samples in all fine materials at least every 5 feet from 10 to 25 feet. Samples should be taken out frozen and should be tested for volumetric change during thawing and for bearing strength after thawing. Shaft should be excavated without thawing the ground.

d. If materials without bearing strength when thawed are found in the shafts or if evidence of excessive settlement develops, a cooling system to maintain the ground in a frozen condition should be installed. The endeavor should be to place the level of cooling as fast as possible below the warm floor. It seems probable that the best procedure would be to take out the present floor slab, excavate to a depth of 2 feet or more, lay reinforcing steel at about 6-inch centers to pick up the heat, and lay cooling pipes in close contact upon the steel. It may be desirable to embed this system in a concrete slab for protection. Backfills should be of cinders or better insulator and the floor slab laid on the cinders. The rate of heat transfer in such a system would be about 10 B.T.U. per hour per square foot or about 30,000 B.T.U. per hour for the whole building. 